\title{
Farmed Gilthead Sea Bream (Sparus aurata) by-Products Valorization: Viscera Oil $\omega-3$ Enrichment by Short-Path Distillation and In Vitro Bioactivity Evaluation
}

\author{
Concetta Maria Messina ${ }^{1} \mathbb{D}, \operatorname{Rosaria}_{\text {Arena }}{ }^{1} \mathbb{D}$, Simona Manuguerra $^{1} \mathbb{D}$, Giuseppe Renda $^{1}$, \\ Vincenzo Alessandro Laudicella ${ }^{2}$, Giovanna Ficano ${ }^{1}$ (D) , Gioacchino Fazio ${ }^{3}$, Laura La Barbera ${ }^{2}$ (D) \\ and Andrea Santulli 1,2,*iD
}

Citation: Messina, C.M.; Arena, R.; Manuguerra, S.; Renda, G.; Laudicella, V.A.; Ficano, G.; Fazio, G.; La Barbera, L.; Santulli, A. Farmed Gilthead Sea Bream (Sparus aurata) by-Products Valorization: Viscera Oil $\omega-3$ Enrichment by Short-Path Distillation and In Vitro Bioactivity Evaluation. Mar. Drugs 2021, 19, 160. https://doi.org/10.3390/ md19030160

Academic Editor: Bill J. Baker

Received: 31 December 2020

Accepted: 11 March 2021

Published: 18 March 2021

Publisher's Note: MDPI stays neutral with regard to jurisdictional claims in published maps and institutional affiliations.

Copyright: (c) 2021 by the authors Licensee MDPI, Basel, Switzerland. This article is an open access article distributed under the terms and conditions of the Creative Commons Attribution (CC BY) license (https:// creativecommons.org/licenses/by/ $4.0 /)$
1 Laboratorio di Biochimica Marina ed Ecotossicologia, Dipartimento di Scienze della Terra e del Mare DiSTeM, Università degli Studi di Palermo, Via G. Barlotta 4, 91100 Trapani, Italy; concetta.messina@unipa.it (C.M.M.); rosaria.arena@unipa.it (R.A.); simona.manuguerra@unipa.it (S.M.); giuseppe.renda02@unipa.it (G.R.); giovanna.ficano@unipa.it (G.F.)

2 Istituto di Biologia Marina, Consorzio Universitario della Provincia di Trapani, Via G. Barlotta 4, 91100 Trapani, Italy; alessandro.laudicella@gmail.com (V.A.L.); labarbera@consunitp.it (L.L.B.)

3 Dipartimento di Science Economiche, Aziendali e Statistiche, DSEAS, Università degli Studi di Palermo, Viale delle Scienze, Edificio 13, 90100 Palermo, Italy; gioacchino.fazio@unipa.it

* Correspondence: andrea.santulli@unipa.it

\begin{abstract}
This study shows a pilot scale protocol aimed to obtain an omega 3-enriched oil after the processing of farmed gilthead sea bream viscera (SBV); this was oil was tested in vitro for bioactivity, attesting to the possibility to turn waste into profit The quality of the oil, in terms of requirements for animal and human consumption, was assessed by determining some chemical parameters, such as peroxide value (PV), thiobarbituric acid reactive substances (TBARS), $\rho$-anisidine ( $\rho$-AV) content, total oxidation value (TOTOX), and phospholipids and free fatty acid (\%), both in crude viscera oil $(\mathrm{CVO})$ and refined viscera oil (RVO). Among the extraction conditions, the higher $\mathrm{CVO}$ yields were obtained at $60^{\circ} \mathrm{C}$ for $10 \mathrm{~min}(57.89 \%)$ and at $80^{\circ} \mathrm{C}$ for $10 \mathrm{~min}(67.5 \%)$, and the resulting oxidation levels were low when utilizing both extraction conditions. RVO, obtained from CVO extracted at $60{ }^{\circ} \mathrm{C}$, showed the highest quality on the basis of the assessed parameters. The ethyl esters of the total fatty acid (TFA) contents extracted from RVO were enriched in the $\omega-3$ polyunsaturated fatty acid fraction (PUFAE) up to almost $56 \%$ via short path distillation (SPD). Antioxidant activities and adipogenic properties were tested in vitro. PUFAE protected 3T3 L1 cells from oxidative stress and exerted an anti-adipogenic effect in Dicentrarchus labrax pre-adipocytes, attesting to the beneficial properties for both farmed fish and human health. These results could stimulate the adoption of solutions aimed to recover and utilize aquaculture by-products at a higher scale, turning "waste into profit" and indicating a strategy to reach more sustainable business models in aquaculture resource utilization according to the principles of the circular economy.
\end{abstract}

Keywords: aquaculture; by-products; omega-3 fatty acids; fish oils; nutraceutics

\section{Introduction}

The increasing pressure on natural resources has resulted in an urgent need to optimize the destiny of the by-products of the main food supply chains.

The reduction of food loss and waste, as well as their valorization, is crucial to achieve the goal of "zero waste". Considering that environmental sustainability is closely linked to economic sustainability, scientific and technical knowledge is essential to outline the road map of more sustainable business models and to optimize the efficiency of aquatic resource utilization [1-3], according to the 2030 agenda. In view to target the 14th Sustainable Development Goal (SDG) of the United Nations Development Programme (UNDP) (devoted to the proper utilization of the "resources below the water") and considering the pivotal 
role of aquaculture in satisfying the global demand for fish products, the contribution of this industry to the production of by-products must be properly managed at the national and regional levels.

It is well-known that marine oils are an excellent source of $\omega-3$ long chain, polyunsaturated fatty acids (PUFAs), including eicosapentaenoic acid (EPA) and docosahexaenoic acid (DHA). These particular classes of PUFA are common in marine organisms; in particular, PUFAs are synthesized in microalgae and tend to significantly accumulate in fatty fish and in the oil extracted from these organisms and their by-products [1,4-9].

In recent years, there has been an exponential growth in the market of the $\omega-3$ PUFAs for human consumption, thanks to numerous studies showing the significant beneficial effects determined by fish oil and $\omega-3$ PUFA-rich functional foods daily consumption in terms of dietetic $[6,10]$ anti-tumor $[6,11-14]$, and antithrombotic properties $[5,15,16]$.

In addition, the demand for $\omega-3$ PUFA fish oils for animal feeds, in particular for aquaculture, has also been rapidly growing [17-19] due to the recognized beneficial effects on growth performance, nutritional value [20-23], and immune system of reared fish [24].

As the industrial production of fish oil is based on the intensive fishing of fatty fish species belonging to the families such as Scomberesocidae, Gadidae, and Clupeidae, with a consequent depletion of wild fish stocks, it is important to identify new sources for the industrial production of PUFA-rich oils and $\omega-3$ PUFA concentrates $[7,25]$.

In this context, the use of fisheries and aquaculture by-products and wastes as raw material can be an important resource that still contains a large amount of components with high nutritional value, such as $\omega-3$ PUFA [7,16,26-32].

By-products from processed farmed fish are extremely interesting because they are obtained from a highly controlled processing chain [19], with a high organoleptic quality [21] and a high content of oils and fats that-if properly stored, processed, and enriched-can provide a high amount of $\omega-3$ PUFA for direct human consumption $[33,34]$ with significant beneficial effects $[3,6,10,11,16]$. In particular, in the wide range of beneficial effects, several studies have suggested that $\omega-3$ PUFA also has antioxidant, anti-inflammatory, and antiadipogenic effects. These effects, with important nutritional and nutraceutical implications, have been demonstrated in vitro on different cell lines [35-38].

The utilization of by-products from fisheries and aquaculture, according to the principles of the circular economy, will turn "waste into profit", indicating more sustainable business models and optimizing the efficiency of aquatic resource utilization [1]. Companies, in fact, will have a direct economic return from the commercialization of bio-products and an indirect return from the reduction waste to be sent to landfills $[25,39,40]$. This last aspect will also allow for a positive environmental impact by reducing the pressure on the environment of these productive activities [8].

About $30 \%$ of the total marine aquaculture production in Sicily (around $2.000 \mathrm{t} /$ year) is minimally processed (gilled, gutted, and fillet) and marketed at local markets or in large-scale distribution. We estimate that, on the regional scale, reared seabass and sea bream processing guarantees a production of $36 / 40 \mathrm{t} /$ year of viscera, with this component being about $6 / 7 \%$ of the total by-product.

In the main Sicilian fish farm, wastes from processed fish are automatically collected during the production cycle, stored, and sent to landfills. In agreement with this farm, as part of an industrial research project, we developed a pilot process for the recovery and valorization of this waste with the aim to turn "waste into profit" and contribute to increasing the economic and environmental sustainability of aquaculture as a paradigm of the circular economy.

The aim of this research was to develop and optimize methods for the separation of crude viscera oil (CVO) taken from reared sea bream (Sparus aurata) viscera (SBV) and its refinement to obtain refined viscera oil (RVO) by short path distillation (SPD). After transesterification to produce total fatty acid (TFA) ethyl esters from RVO, SPD was employed to enrich the $\omega-3$ PUFA fraction (PUFAE) and separate the exhausted fatty acid ethyl esters fraction (EFA). On refined oil and separated fractions, bioactive properties were 
evaluated in vitro to investigate the potential antioxidant effects in the 3T3-L1 cell line and anti-adipogenic effects in primary pre-adipocytes of Dicentrarchus labrax.

\section{Results and Discussion}

\subsection{Proximate Composition of Sea Bream Viscera (SBV) By-Product}

The proximate composition of SBV (Table 1) showed a high total lipid content $(51.79 \pm 12.92 \%)$ and moisture, protein, and ash values of $40.81 \pm 4.86 \%, 5.67 \pm 0.02 \%$, and $1.43 \pm 0.55 \%$, respectively (Table 1).

Table 1. Proximate composition of sea bream viscera (SBV) by-product (mean \pm standard deviation values; $n=12$ ).

\begin{tabular}{cc}
\hline Parameters & g/100 g SBV \\
\hline Lipid & $51.79 \pm 12.92$ \\
Moisture & $40.81 \pm 4.86$ \\
Protein & $5.67 \pm 0.02$ \\
Ash & $1.43 \pm 0.55$ \\
\hline
\end{tabular}

The total lipid content was higher than the data reported in the literature by Pateiro et al. [8] (34.11\% in the guts and $25.76 \%$ in the liver of reared sea bream), Rincón Cervera et al. [33] (34\% in the viscera of sea bream from semi-extensive farming), and Sinanoglou et al. [41] ( $29.92 \pm 3.5 \%$ under organic and $42.61 \pm 5.29 \%$ under conventional production systems). Kandyliari et al. [42] showed a total lipid content equal to $43.19 \%$ (large size) and 55.12\% (small size) in the intestine of sea bream reared in a pilot-scale cage farm.

These diverse data confirm that lipid content in fish tissues is significant influenced by rearing conditions. The reared sea bream, also due to the considerable availability of artificial food, usually shows a greater accumulation of fat when compared to wild specimens, and, as expected, the fatty acid profile tends to reflect that of the administered diet $[8,33,41,43,44]$.

The fatty acid profile of SBV total lipids is shown in Table 2.

Table 2. Fatty acid profile (\%) of the total lipids in sea bream viscera (SBV) (mean \pm standard deviation values; $n=12$ ). EPA: eicosapentaenoic acid; DHA: docosahexaenoic acid; SFA: saturated fatty acid; MUFA: monounsaturated fatty acids; PUFA: polyunsaturated fatty acid.

\begin{tabular}{cc}
\hline Fatty Acids & $\%$ \\
\hline $14: 0$ & $4.99 \pm 0.17$ \\
$16: 0$ & $15.56 \pm 0.18$ \\
$16: 1 n-7$ & $10.72 \pm 0.18$ \\
$16: 2 n-4$ & $0.89 \pm 0.03$ \\
$16: 3 n-4$ & $0.59 \pm 0.02$ \\
$18: 0$ & $2.96 \pm 0.06$ \\
$18: 1 n-9$ & $16.11 \pm 0.40$ \\
$18: 1 n-7$ & $6.05 \pm 0.15$ \\
$18: 2 n-6$ & $2.42 \pm 0.16$ \\
$18: 3 n-4$ & $0.01 \pm 0.00$ \\
$18: 3 n-3$ & $0.62 \pm 0.04$ \\
$18: 4 n-3$ & $1.68 \pm 0.06$ \\
$20: 1 n-9$ & $11.14 \pm 0.27$ \\
$20: 4 n-6$ & $0.13 \pm 0.03$ \\
$20: 4 n-3$ & $0.38 \pm 0.08$ \\
EPA & $8.19 \pm 0.12$ \\
$22: 1 n-11$ & $4.71 \pm 0.17$ \\
$22: 1 n-9$ & $0.38 \pm 0.02$ \\
$22: 5 n-3$ & $1.19 \pm 0.08$ \\
\hline
\end{tabular}


Table 2. Cont.

\begin{tabular}{cc}
\hline Fatty Acids & $\%$ \\
\hline DHA & $11.27 \pm 0.30$ \\
SFA & $23.51 \pm 0.28$ \\
MUFA & $49.12 \pm 0.76$ \\
PUFA & $27.38 \pm 0.48$ \\
\hline
\end{tabular}

Monounsaturated fatty acids (MUFAs) were the most abundant class of fatty acids $(49.13 \pm 0.76 \%)$, followed by PUFAs $(27.38 \pm 0.48 \%)$ and saturated fatty acids (SFAs) $(23.51 \pm 0.28 \%)$. The predominant fatty acid was oleic acid $(18: 1 \mathrm{n} 9,16.11 \pm 0.40 \%)$ (Table 2$)$. This profile was comparable to results reported by other authors for reared sea bream by-products $[8,33,41,42]$ and was in accordance with the observation that the relative proportion of oleic acid is not strictly affected by the rearing system [41]. For reared species, such as sea bass and sea bream, numerous data in the literature attest to the direct effect of the diets on tissues fatty acid composition and, consequently, on the nutritional, organoleptic and shelf life properties of the products [22,33,41-46]. In particular, increasing levels of $\omega-6$ PUFA are known to result from the supplementation of fish feed with vegetable oils, which increases the proportion of dietary C18:2 n-6 [18,41,45,47].

As expected, this parameter is also strictly subjected to quantitative and qualitative variations in relation to life cycle, diet, and other ecological factors [18,22,30,41,45,47]].

Among PUFAs, the predominant fatty acids were EPA and DHA $(8.19 \pm 0.12 \%$ and $11.27 \pm 0.30$, respectively) (Table 2). Pateiro et al. [8] showed a lower content of total long-chain PUFA but a higher contents of EPA and DHA, while data reported by Rincón Cervera et al. [33] showed a lower content of EPA and a higher content of DHA in sea bass and sea bream by-products [33]. Moreover, the sum of EPA and DHA content, in our study, was higher when compared to that reported by Maschmeyer et al. [30] in sea bass and sea bream by-products, probably as a consequence of the administered diet.

\subsection{Yield and Quality of Crude Viscera Oil (CVO)}

The monitoring of the extraction process was carried out by evaluating the percentage of oil recovery (\%) (Figure 1) and the quality parameters, as shown in Table 3.

An increase of CVO yield was observed as the reaction temperature rose (Figure 1). The yield, calculated on the total lipid content of SBV, increased from $38.46 \pm 2.43 \%$ at $40{ }^{\circ} \mathrm{C}$ for $10 \mathrm{~min}$ to $67.51 \pm 2.60 \%$ at $80{ }^{\circ} \mathrm{C}$ for $10 \mathrm{~min}$ (Figure 1 ). These results confirmed that, as already reported [48-50], higher temperatures are preferential to increase the extraction yield.

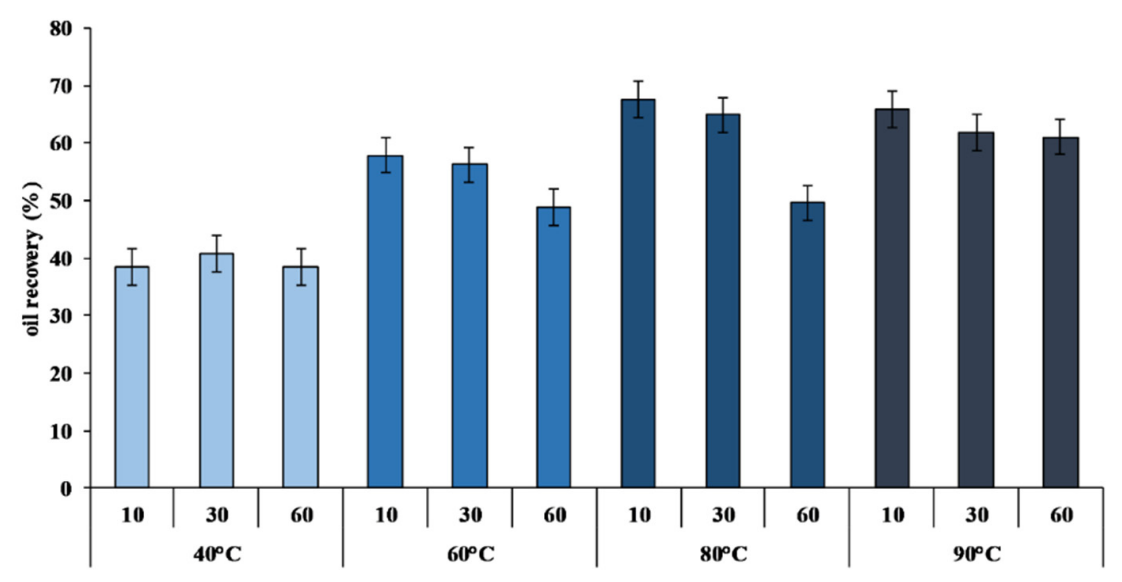

Figure 1. Percentage of crude viscera oil (CVO) recovery calculated on the total lipid content of sea bream viscera (SBV) at different temperatures $\left(40,60,80\right.$, and $\left.90^{\circ} \mathrm{C}\right)$ and different extraction times $\left(10^{\prime}, 30^{\prime}\right.$, and $\left.60^{\prime}\right)(n=12)$. 
Table 3. Quality of crude viscera oil (CVO) extracted at different temperatures $\left(40,60,80\right.$, and $\left.90^{\circ} \mathrm{C}\right)$ and different extraction times $\left(10^{\prime}, 30^{\prime}\right.$, and $\left.60^{\prime}\right)$, as determined by the evaluation of peroxide value (PV; meqO $2 / \mathrm{kg}$ ) and thiobarbituric acid reactive substances (TBARS) (MDA $\mu \mathrm{g} / \mathrm{g}$ ). Commercial cod liver oil was used as the control oil (CO).

\begin{tabular}{cccc}
\hline & Sample & \multicolumn{2}{c}{ Parameters } \\
\hline Temperatures & Times & PV & TBARS \\
\hline \multirow{2}{*}{40} & 10 & $6.17 \pm 0.47^{\mathrm{b}}$ & $16.01 \pm 0.02^{\mathrm{b}}$ \\
& 30 & $6.51 \pm 0.22^{\mathrm{b}}$ & $15.59 \pm 0.03^{\mathrm{b}}$ \\
& 60 & $10.29 \pm 2.37^{\mathrm{c}}$ & $21.18 \pm 5.85^{\mathrm{bc}}$ \\
\hline \multirow{2}{*}{60} & 10 & $5.42 \pm 0.13^{\mathrm{b}}$ & $14.15 \pm 0.07^{\mathrm{b}}$ \\
& 30 & $6.38 \pm 0.03^{\mathrm{b}}$ & $16.58 \pm 0.01^{\mathrm{b}}$ \\
& 60 & $11.33 \pm 0.75^{\mathrm{cd}}$ & $14.31 \pm 0.22^{\mathrm{b}}$ \\
\hline \multirow{2}{*}{80} & 10 & $11.01 \pm 1.77^{\mathrm{cd}}$ & $17.50 \pm 2.41^{\mathrm{b}}$ \\
& 30 & $13.27 \pm 2.13^{\mathrm{d}}$ & $25.38 \pm 8.59^{\mathrm{c}}$ \\
& 60 & $19.69 \pm 0.90^{\mathrm{e}}$ & $19.89 \pm 2.29^{\mathrm{bc}}$ \\
\hline & 10 & $10.99 \pm 0.53^{\mathrm{cd}}$ & $31.41 \pm 6.33^{\mathrm{d}}$ \\
& 30 & $19.67 \pm 2.10^{\mathrm{e}}$ & $33.09 \pm 1.31^{\mathrm{d}}$ \\
& 60 & $22.74 \pm 2.27^{\mathrm{f}}$ & $33.43 \pm 5.63^{\mathrm{d}}$ \\
\hline
\end{tabular}

Different superscript letters in the same column indicate significant differences $(a, b, c \ldots: p<0.05)$. The data are reported as mean \pm standard deviation $(n=12)$.

Under optimal extraction conditions, without the use of any solvents, the procedure we have described allows us to extract and separate about $6.5 \mathrm{~L}$ of oil from $20 \mathrm{~kg}$ of viscera in about three hours.

The evaluation of primary and secondary lipid oxidation markers like peroxide value $(\mathrm{PV})$ and thiobarbituric acid reactive substances (TBARS) showed that these compounds were highly influenced by the extraction conditions. It is known that higher temperatures promote lipid oxidation, which leads to a decrease in oil quality [48]. The peroxide content ranged from $5.42 \pm 0.13 \mathrm{meq} \mathrm{O}_{2} / \mathrm{kg}$ in CVO extracted at $60^{\circ} \mathrm{C}$ for $10 \mathrm{~min}$ to a maximum of $22.74 \pm 2.27 \mathrm{meq} \mathrm{O}_{2} / \mathrm{kg}$ in CVO extracted at $90^{\circ} \mathrm{C}$ for $60 \mathrm{~min}$ (Table 3). The maximum PVs were recorded in CVO extracted at $60 \mathrm{~min}$, rather than 10 and $30 \mathrm{~min}$, at each temperature (Table 3) $(p<0.05)$.

The PV in CVO was higher than values registered in the commercial cod liver oil control oil (CO) for human consumption $\left(2.10 \pm 0.53 \mathrm{meq} \mathrm{O}_{2} / \mathrm{kg}\right)$ (Table 3). None of the $\mathrm{CVO}$ we extracted from SBV showed a content lower than 5 meq $\mathrm{O}_{2} / \mathrm{kg}$, so it was necessary to refine it for the human consumption and, in any case, for further applications [51,52].

The increase of oxidation parameters at higher temperatures (Table 3) was comparable to the yield and quality of Oncorhynchus nerka [53] and Clarias gariepinus [54].

The evaluation of lipid oxidation by TBARS, expressed as the content of malondialdehyde (MDA) in oil ( $\mu \mathrm{g} / \mathrm{g}$ ), showed a comparable trend to the PV content (Table 3). TBARS content, in fact, increased in relation to CVO extraction temperature (Table 3 ) from $14.15 \pm 0.0$, at $60^{\circ} \mathrm{C}$ for $10 \mathrm{~min}$ to a maximum of $33.43 \pm 5.63$ at $90^{\circ} \mathrm{C}$ for $60 \mathrm{~min}$ (Table 3). In any case, the TBARS content of CVO was higher than the TBARS content of the reference oil (CO: $5.51 \pm 0.81 \mathrm{MDA} \mu \mathrm{g} / \mathrm{g}$ ) (Table 3). However, the TBARS content of CVO (Table 3) was lower than the values observed by Šimat et al. $[25,34]$ in crude oil extracted from sea bass and sea bream guts.

At higher extraction temperatures, we reported an alteration of CVO color (Table S1). From the CIELab coordinates [55], we observed a variation from yellow (parameter $b^{*}$ ) in CVO extracted at 40 and $60^{\circ} \mathrm{C}$ to red (parameter a*) in CVO extracted at 80 and $90^{\circ} \mathrm{C}$ (Table S1 and Figure S1). Furthermore, the increase of extraction temperature also led to a reduction of CVO lightness (parameter $\mathrm{L}^{*}$ ) (Table S1). In any case, the color of all our CVO was always different from the color of the reference oil (CO) $(p<0.05)$ (Table S1). 
The high temperature extraction-induced lipid oxidation that determined a variation of the extracted oil color [53,56-58].

Thus, extracted oil color evaluation could be utilized as quick and cheap oil quality marker.

The variation of the CVO's main classes of fatty acids, on the basis of extraction temperature, is shown in Table 4.

Table 4. Main classes of fatty acids (\%) extracted from sea bream viscera (SBV) and crude viscera oil (CVO) after extraction at different temperatures $\left({ }^{\circ} \mathrm{C}\right)$ and reaction times $(\mathrm{min})$.

\begin{tabular}{|c|c|c|c|c|c|c|}
\hline \multicolumn{2}{|c|}{ Samples } & SFA & MUFA & PUFA & EPA & DHA \\
\hline \multicolumn{2}{|c|}{ SBV } & $23.51 \pm 0.28^{a}$ & $49.12 \pm 0.76^{a b}$ & $27.38 \pm 0.48^{e}$ & $8.19 \pm 0.12^{\mathrm{eg}}$ & $11.27 \pm 0.30^{\mathrm{e}}$ \\
\hline \multicolumn{7}{|c|}{ CVO } \\
\hline \multirow[t]{2}{*}{ Temperature } & Time & & & & & \\
\hline & 10 & $24.98 \pm 1.03^{a b}$ & $50.09 \pm 0.66^{b}$ & $24.93 \pm 0.37 \mathrm{bcd}$ & $7.12 \pm 0.52^{b c d}$ & $10.15 \pm 0.06^{\mathrm{cd}}$ \\
\hline \multirow[t]{2}{*}{40} & 30 & $24.26 \pm 0.58^{\mathrm{a}}$ & $50.28 \pm 0.15^{b}$ & $25.46 \pm 0.58^{\text {cde }}$ & $7,78 \pm 0.18^{\text {def }}$ & $10.03 \pm 0.36^{\mathrm{cd}}$ \\
\hline & 60 & $26.61 \pm 1.35 \mathrm{bc}$ & $49.81 \pm 0.28^{\mathrm{b}}$ & $23.58 \pm 1.64 \mathrm{bc}$ & $6.91 \pm 0.51 \mathrm{bc}$ & $9.25 \pm 1.00 \mathrm{bc}$ \\
\hline \multirow{3}{*}{60} & 10 & $25.28 \pm 0.01^{\mathrm{ab}}$ & $49.84 \pm 0.11^{b}$ & $24.88 \pm 0.10^{b c d}$ & $7.54 \pm 0.05^{\text {cdef }}$ & $9.69 \pm 0.02 \mathrm{bcd}$ \\
\hline & 30 & $25.69 \pm 1.41^{\mathrm{abc}}$ & $49.43 \pm 0.06^{\mathrm{b}}$ & $24.88 \pm 1.36^{b c d}$ & $7.71 \pm 0.56^{\mathrm{def}}$ & $9.61 \pm 0.49 \mathrm{bcd}$ \\
\hline & 60 & $25.17 \pm 0.79 \mathrm{ab}$ & $48.86 \pm 0.49^{b}$ & $25.97 \pm 1.28^{\mathrm{de}}$ & $7.92 \pm 0.69$ ef & $9.85 \pm 0.67^{\mathrm{cd}}$ \\
\hline \multirow{3}{*}{80} & 10 & $26.62 \pm 1.66^{b c}$ & $47.41 \pm 0.69^{a}$ & $25.97 \pm 2.35^{\mathrm{de}}$ & $7.56 \pm 0.35^{\text {cdef }}$ & $10.49 \pm 1.37^{\text {de }}$ \\
\hline & 30 & $27.23 \pm 0.80^{c}$ & $49.83 \pm 0.42^{b}$ & $22.94 \pm 0.37^{b}$ & $6.73 \pm 0.08^{b}$ & $8.71 \pm 0.37^{a b}$ \\
\hline & 60 & $24.78 \pm 0.77^{\mathrm{a}}$ & $49.42 \pm 0.38^{\mathrm{b}}$ & $25.79 \pm 1.15^{\text {cde }}$ & $7.38 \pm 0.56^{\text {bcde }}$ & $10.61 \pm 0.54^{\text {de }}$ \\
\hline \multirow{3}{*}{90} & 10 & $24.48 \pm 0.62^{a}$ & $48.54 \pm 0.33^{\mathrm{ab}}$ & $26.98 \pm 0.97 \mathrm{de}$ & $8.64 \pm 0.42 g$ & $10.40 \pm 0.52$ cde \\
\hline & 30 & $25.25 \pm 0.76^{\mathrm{ab}}$ & $48.72 \pm 0.39^{b}$ & $25.76 \pm 0.84$ cde & $7.44 \pm 0.30$ cdef & $9.68 \pm 0.45 \mathrm{bcd}$ \\
\hline & 60 & $26.69 \pm 0.21 \mathrm{bc}$ & $52.30 \pm 2.75^{c}$ & $21.02 \pm 1.90^{\mathrm{a}}$ & $6.09 \pm 0.45^{\mathrm{a}}$ & $7.97 \pm 0.43^{\mathrm{a}}$ \\
\hline
\end{tabular}

Different superscript letters in the same column indicate significant differences $(a, b, c \ldots: p<0.05)$. The data are reported as mean \pm standard deviation $(n=12)$.

A significant reduction in PUFA was observed as the temperature increased, with a significantly lower value in the oil extracted at $90^{\circ}$ for $60 \mathrm{~min}(p<0.05)$. It is known in literature, in fact, that high temperatures lead to the thermal degradation of some polyunsaturated fatty acids [59].

However, at the highest extraction temperature, the EPA and DHA contents were higher than those observed by Šimat et al. $[25,34]$ in crude oil extracted from sea bass and sea bream by-products under similar conditions $\left(95^{\circ} \mathrm{C}\right.$ for $12 \mathrm{~min}$ ).

The evaluation of the yield and quality parameters of the extracted CVO confirmed that the extraction conditions directly affected the oil yield, reaching a maximum value in $\mathrm{CVO}$ extracted at $80^{\circ} \mathrm{C}$ (Figure 1). In addition, at high temperatures, a higher level of lipid oxidation was observed, as evidenced by the increase in the value of peroxides and TBARS (Table 3), especially at longer reaction times. However, the quality of CVO extracted at $60{ }^{\circ} \mathrm{C}$ for $10 \mathrm{~min}$ and $80^{\circ} \mathrm{C}$ for $10 \mathrm{~min}$ was within the guidelines for the evaluation of primary and secondary lipid oxidation markers of unprocessed fish oils that were recently published by the European Food Safety Agency [60]. For this reason, we chose to test the refining process on $\mathrm{CVO} 60^{\circ} \mathrm{C} 10 \mathrm{~min}$ and $\mathrm{CVO}$ extracted at $80^{\circ} \mathrm{C} 10 \mathrm{~min}$ because these the extraction conditions that offered the highest quality combined with a good product yield.

\subsection{Crude Oil Refining: Effects of the Chemical Processes on Oil Quality}

Crude fish oil is not suitable for direct human consumption, and further processing is need $[25,52,60,61]$. Phospholipids, water, free fatty acids, mono and di-glycerides, pigments, hydrocarbons, sterols, vitamins, pigments, carbohydrates, proteins, and lipid oxidation products may give undesirable flavors and colors $[25,52,60,61]$. The refining process is necessary to improve the quality of crude fish oil. 
With the aim to remove undesirable components, CVO undergoes a refining process to obtain RVO and stabilize it [52,60], as described below.

The effect of the starting CVO quality, extracted at two temperatures $\left(60\right.$ and $\left.80{ }^{\circ} \mathrm{C}\right)$ on the different quality parameters of the final RVO $[25,52,60,62,63]$, are shown in Table 5 .

Table 5. Effect of crude viscera oil (CVO) extraction temperature $\left(60\right.$ and $\left.80^{\circ} \mathrm{C}\right)$ on the quality of refined viscera oil (RVO), as determined by peroxide value: $\mathrm{PV} ; \rho$-anisidine: $\rho$-AV; thiobarbituric acid reactive substances: TBARS; total oxidation value: TOTOX; phospholipids; \% free fatty acid: \%FFA. Commercial cod liver oil was used as the control oil (CO).

\begin{tabular}{|c|c|c|c|c|c|c|c|}
\hline \multirow[b]{2}{*}{ Samples } & \multirow[b]{2}{*}{$\begin{array}{c}\text { CVO } \\
\text { Extraction } \\
\text { Temperature }\end{array}$} & \multicolumn{6}{|c|}{ Parameters } \\
\hline & & $\begin{array}{c}\mathrm{PV} \\
\left(\mathrm{meqO}_{2} / \mathrm{kg}\right)\end{array}$ & $\rho-A V$ & $\begin{array}{c}\text { TBARS } \\
(\text { MDA } \mu \mathrm{g} / \mathrm{g})\end{array}$ & TOTOX & $\begin{array}{l}\text { Phospholipids } \\
\quad\left(\mathrm{mg} \mathrm{kg}^{-1}\right)\end{array}$ & $\begin{array}{l}\text { Acid Value } \\
\text { (\%FFA) }\end{array}$ \\
\hline $\mathrm{CVO}$ & & $5.41 \pm 0.14^{b}$ & $28.98 \pm 0.90^{\mathrm{d}}$ & $14.15 \pm 0.07^{\mathrm{d}}$ & $39.80 \pm 1.18^{c}$ & $24.75 \pm 1.61^{\mathrm{d}}$ & $8.23 \pm 0.82^{d}$ \\
\hline RVO & & $3.90 \pm 1.15^{b}$ & $13.49 \pm 0.20^{b}$ & $6.62 \pm 0.39^{b}$ & $21.30 \pm 2.50^{b}$ & $8.00 \pm 1.10^{a}$ & $1.74 \pm 0.33^{b}$ \\
\hline $\mathrm{CVO}$ & & $11.17 \pm 1.31^{\mathrm{d}}$ & $34.56 \pm 2.36^{\mathrm{e}}$ & $17.50 \pm 2.41^{\mathrm{e}}$ & $56.90 \pm 0.26^{\mathrm{e}}$ & $47.47 \pm 14.05^{\mathrm{e}}$ & $7.41 \pm 0.49^{c}$ \\
\hline RVO & $80^{\circ} \mathrm{C}$ & $8.63 \pm 0.31^{c}$ & $24.06 \pm 1.13^{c}$ & $8.96 \pm 0.86^{c}$ & $41.32 \pm 0.51^{\mathrm{d}}$ & $14.42 \pm 3.90^{c}$ & $6.62 \pm 0.74^{c}$ \\
\hline $\mathrm{CO}$ & & $2.10 \pm 0.53^{a}$ & $4.96 \pm 0.89^{a}$ & $5.51 \pm 0.81^{\mathrm{a}}$ & $10.83 \pm 0.24^{a}$ & $10.74 \pm 2.45^{b}$ & $0.50 \pm 0.04^{a}$ \\
\hline
\end{tabular}

Different superscript letters in the same column indicate significant differences $(\mathrm{a}, \mathrm{b}, \mathrm{c} \ldots: p<0.05)$. The data are reported as mean \pm standard deviation $(n=12)$.

Similarly, in the present study, after the refining process of SPD, a decrease in the main parameters related to the lipid components oxidation was observed, in accordance to literature [25,64]. In fact, both primary oxidation components (like PV) and secondary oxidation products (like $\rho$-anisidine $(\rho-\mathrm{AV})$ and TBARS) showed a significant decrease in RVO produced from CVO that was extracted at 60 and $80{ }^{\circ} \mathrm{C}$ (Table 5).

Total oxidation value (TOTOX) also reflected the trend of the previous lipid oxidation markers (Table 5) with a significant decrease in RVO produced from CVO extracted at 60 and $80^{\circ} \mathrm{C}$. These results confirmed the influence of the refining process on oil oxidation status and, in terms of PV and $\rho$-AV of RVO produced from CVO extracted at $60{ }^{\circ} \mathrm{C}$, had results comparable to those observed by Šimat et al. [25]. The values of TOTOX and TBARS (Table 5) in RVO produced from CVO extracted at $60{ }^{\circ} \mathrm{C}$ were lower than those observed by the same authors [25]. The results of this study for the PV, $\rho-\mathrm{AV}$, and TOTOX contents of RVO at $60{ }^{\circ} \mathrm{C}$ were comparable to the values observed by Franklin et al. [58] in oil extracted from yellowtail fish waste by supercritical $\mathrm{CO}_{2}$ extraction [58].

The contents of phospholipids, which act as emulsifiers and increase oil viscosity [30], have been analyzed to evaluate the effectiveness of the degumming, the first step of the refining process. As already reported $[30,65,66], \mathrm{CVO}$ refining determines a reduction of phospholipid content (Table 5) below $10 \mathrm{mg} / \mathrm{kg}$, the optimal suggested value for edible oils $[52,60,63,66]$.

The refining process is also able to remove free fatty acids (FFAs), which are among the most responsible for the characteristic rancid odor as consequence of the oxidation process in the oil [67], thus necessitating the deacidification step in the refining process [66].

Our results showed a significant reduction of FFA in RVO produced from CVO extracted at $60{ }^{\circ} \mathrm{C}$ (Table 5), reaching values lower than $3 \%$, which is the threshold recommended for edible oils $[52,60]$.

Colorimetric analyses showed significant differences $(p<0.05)$ among all considered parameters between CVO and RVO (Table S2). These observations were comparable to those reported in the literature for refined fish oils $[61,68,69]$, confirming that the refining process produces more transparent oil, an increase in the luminosity, and a tendency to be yellow $[61,68,69]$.

It is known that during the refining process, the removal of residues and impurities, such as oxidation products, peroxides, phospholipid, metals, soaps, and organic contaminants, leads to a brightening of the oil, as attested to by an increase of the $\mathrm{L}^{*}$ parameter $[61,68,69]$. 
Kuo et al. [62] observed a different trend with the decrease in the $a^{*}$ value (redness) and increase in the $b^{*}$ value (yellowness) as a result of the removal of some pigments during the cobia liver oil refining process. In fact, the bleaching process could remove some pigments and their secondary products-like aldehydes, ketones, trace metals, and sulfurous compounds-to modify the final color of the refined oil [62].

SPD allows for the use of low temperatures for the deodorization and refining of fish oils, as well as significant decreases of oxidation molecules and free fatty acid contents in treated oil [70]. By utilizing SPD, it is possible to obtain an oil that meet the quality standards for human consumption $[52,60,63]$.

On the basis of the analyzed quality markers, the RVO produced from CVO extracted at $60^{\circ} \mathrm{C}$ (Table 5) is the most appropriate oil for a direct human consumption, according to the current guidelines for fish oil for human consumption ( $\mathrm{PV} \leq 5$ meqO $2 / \mathrm{kg}$; $\rho-\mathrm{AV} \leq 20$; TOTOX $\leq 26$; and AV $\leq 3 \mathrm{mg} \mathrm{KOH} / \mathrm{g}$ ) $[52,60,63]$. The $\omega-3$ PUFA fraction of RVO produced from $\mathrm{CVO}$ extracted at $60^{\circ} \mathrm{C}$ was then enriched by SPD.

\subsection{PUFA Enrichment}

RVO transesterification showed an average yield of $65.5 \pm 3.5 \%$ of TFA.

The obtained TFAs were submitted to SPD to enrich the PUFA content, in the PUFAE fraction, via the elimination of the fraction containing short chain and EFAs.

Fatty acid profiles, determined by gas chromatography, are reported in Figure 2.

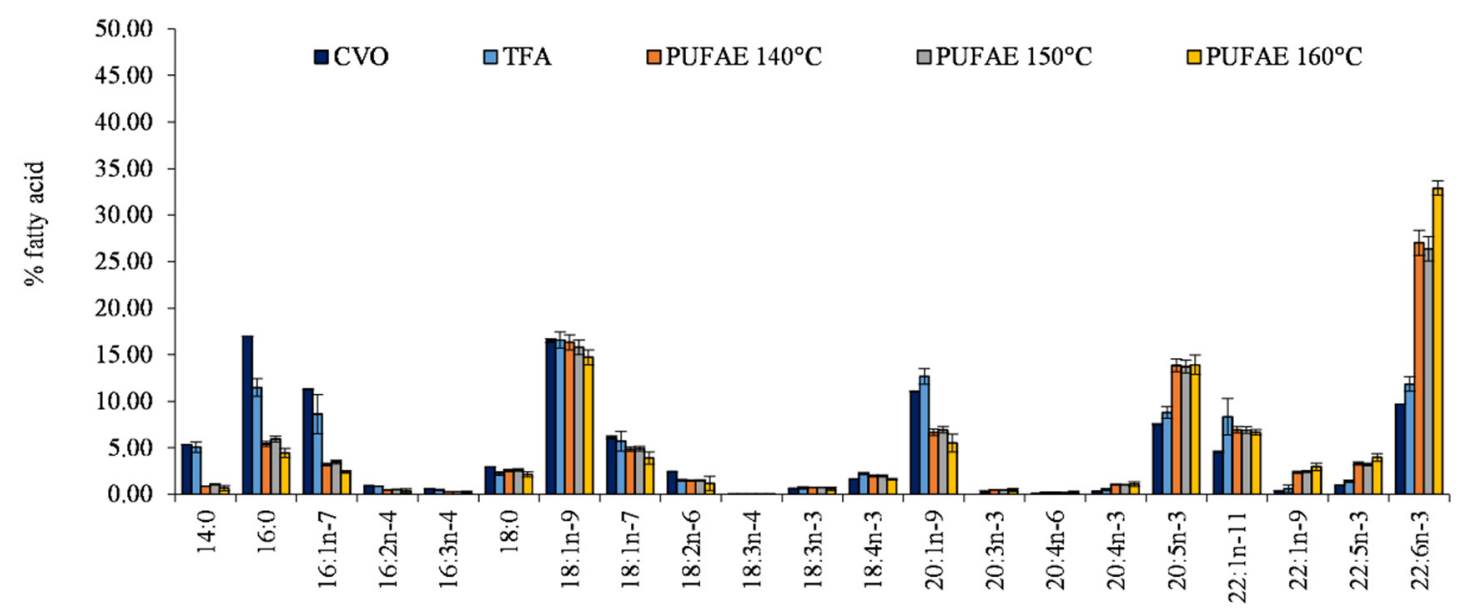

Figure 2. Fatty acid profile (\% fatty acids) of total methyl esters obtained by crude viscera oil (CVO), the total ethyl esters of total fatty acid (TFA), and the fraction enriched in PUFA (PUFAE) by short path distillation (SPD) at the three utilized distillation temperatures of 140,150 , and $160^{\circ} \mathrm{C}$. The data are given as an average of the fatty acid profile from 3 distillations.

Differences among CVO, TFA, and PUFAE fatty acid profiles (Figure 2) confirmed the enrichment effect in PUFA induced by SPD (Figure 2).

After increasing the distillation temperature, an increase of the percentage content of PUFA in PUFAE was observed (Figure 2). In particular, EPA and DHA increased from $8.80 \%$ and $11.84 \%$ in TFA to $13.85 \%$ (EPA) and $27.03 \%$ (DHA) in PUFAE separated at $140{ }^{\circ} \mathrm{C}$, as well as up to $13.92 \%$ (EPA) and $32.90 \%$ (DHA) in PUFAE distillated at $160^{\circ} \mathrm{C}$ (Figure 2).

The enrichment of PUFA by SPD is a consequence of the elimination of the short-chain and saturated fatty acids that, under the operation conditions, were distillated in the light phase [70,71].

In fact, after analyzing the percentage fatty acid contents of TFA, PUFAE, and EFA, separated at the distillation temperature of $160{ }^{\circ} \mathrm{C}$ that showed the best yield (Table 6), this enrichment of PUFAE and the depletion of EFA was evident. 
Table 6. Fatty acid profile (\% fatty acids) and enrichment indexes of the ethyl esters of the total fatty acid (TFA), the fraction enriched in PUFA (PUFAE), and the fraction exhausted in fatty acid ethyl esters (EFA), as obtained by short path distillation (SPD) at $160^{\circ} \mathrm{C}$. The data are reported as mean \pm standard deviation.

\begin{tabular}{|c|c|c|c|}
\hline Fatty Acids & TFA & PUFAE & EFA \\
\hline 14:0 & $5.07 \pm 0.57^{b}$ & $0.66 \pm 0.28^{a}$ & $4.35 \pm 0.05^{b}$ \\
\hline $16: 0$ & $11.47 \pm 0.96^{b}$ & $4.45 \pm 0.46^{\mathrm{a}}$ & $11.26 \pm 0.03^{b}$ \\
\hline $16: 1 n-7$ & $8.63 \pm 2.10^{b}$ & $2.43 \pm 0.16^{\mathrm{a}}$ & $7.48 \pm 0.02^{b}$ \\
\hline $16: 2 n-4$ & $0.86 \pm 0.02^{b}$ & $0.38 \pm 0.21^{\mathrm{a}}$ & $1.01 \pm 0.06^{b}$ \\
\hline $16: 3 n-4$ & $0.48 \pm 0.06^{\mathrm{b}}$ & $0.22 \pm 0.12^{\mathrm{a}}$ & $0.65 \pm 0.08^{b}$ \\
\hline $18: 0$ & $2.24 \pm 0.19$ & $2.15 \pm 0.28$ & $2.36 \pm 0.23$ \\
\hline $18: 1 n-9$ & $16.58 \pm 0.87^{b}$ & $14.72 \pm 0.77^{\mathrm{a}}$ & $18.32 \pm 0.27^{b}$ \\
\hline $18: 1 n-7$ & $5.71 \pm 1.07$ & $3.90 \pm 0.66$ & $5.27 \pm 0.57$ \\
\hline $18: 2 n-6$ & $1.48 \pm 0.13$ & $1.17 \pm 0.75$ & $1.78 \pm 0.06$ \\
\hline $18: 3 n-4$ & $0.01 \pm 0.01^{\mathrm{a}}$ & $0.02 \pm 0.01^{\mathrm{a}}$ & $0.17 \pm 0.00^{b}$ \\
\hline $18: 3 n-3$ & $0.69 \pm 0.11^{\mathrm{a}}$ & $0.60 \pm 0.19^{a}$ & $0.95 \pm 0.02^{b}$ \\
\hline $18: 4 n-3$ & $2.23 \pm 0.11^{b}$ & $1.61 \pm 0.10^{\mathrm{a}}$ & $2.48 \pm 0.14^{\mathrm{c}}$ \\
\hline $20: 1 n-9$ & $12.67 \pm 0.83^{b}$ & $5.51 \pm 0.95^{\mathrm{a}}$ & $11.44 \pm 0.05^{b}$ \\
\hline $20: 3 n-3$ & $0.22 \pm 0.19$ & $0.48 \pm 0.18$ & $0.43 \pm 0.00$ \\
\hline $20: 4 n-6$ & $0.16 \pm 0.08$ & $0.20 \pm 0.14$ & $0.26 \pm 0.00$ \\
\hline $20: 4 n-3$ & $0.53 \pm 0.11^{\mathrm{a}}$ & $1.09 \pm 0.25^{b}$ & $0.97 \pm 0.01^{b}$ \\
\hline EPA-20:5n-3 & $8.80 \pm 0.63^{a}$ & $13.92 \pm 1.05^{b}$ & $9.28 \pm 0.03^{\mathrm{a}}$ \\
\hline $22: 1 n-11$ & $8.33 \pm 1.95^{b}$ & $6.67 \pm 0.28^{a}$ & $8.31 \pm 0.19^{b}$ \\
\hline $22: 1 n-9$ & $0.59 \pm 0.39^{a}$ & $2.96 \pm 0.38^{b}$ & $1.03 \pm 0.05^{\mathrm{a}}$ \\
\hline $22: 5 n-3$ & $1.39 \pm 0.11^{\mathrm{a}}$ & $3.97 \pm 0.42^{b}$ & $1.40 \pm 0.05^{\mathrm{a}}$ \\
\hline DHA-22:6n-3 & $11.84 \pm 0.78^{\mathrm{a}}$ & $32.90 \pm 0.76^{b}$ & $10.78 \pm 0.19^{a}$ \\
\hline SFA & $18.78 \pm 1.29^{a}$ & $7.27 \pm 0.17^{b}$ & $17.97 \pm 0.19^{a}$ \\
\hline MUFA & $52.51 \pm 0.95^{b}$ & $36.19 \pm 0.88^{a}$ & $51.84 \pm 0.24^{b}$ \\
\hline PUFA & $28.71 \pm 2.11^{\mathrm{a}}$ & $56.55 \pm 0.93^{b}$ & $30.19 \pm 0.14^{a}$ \\
\hline $\mathrm{R}$ & $0.74 \pm 0.05^{\mathrm{a}}$ & $2.45 \pm 0.20^{b}$ & $0.68 \pm 0.01^{\mathrm{a}}$ \\
\hline EPA Enrichment Factor & $1.00 \pm 0.07^{\mathrm{a}}$ & $1.58 \pm 0.12^{b}$ & $1.05 \pm 0.00^{\mathrm{a}}$ \\
\hline DHA Enrichment Factor & $1.00 \pm 0.07^{\mathrm{a}}$ & $2.78 \pm 0.06^{\mathrm{b}}$ & $0.91 \pm 0.02^{\mathrm{a}}$ \\
\hline PUFA enrichment facto & $1.00 \pm 0.07^{\mathrm{a}}$ & $1.97 \pm 0.03^{b}$ & $1.05 \pm 0.00^{\mathrm{a}}$ \\
\hline PUFA/SFA & $1.54 \pm 0.21^{\mathrm{a}}$ & $7.79 \pm 0.26^{b}$ & $1.68 \pm 0.02^{\mathrm{a}}$ \\
\hline
\end{tabular}

Different superscript letters in the same row indicate significant differences $(\mathrm{a}, \mathrm{b}, \mathrm{c} \ldots: p<0.05)$. The data are reported as mean \pm standard deviation, $n=12$.

The observed decrease in short-chain and saturated fatty acid percentage contents in PUFAE was a consequence of their distillation in the light fraction, EFA (Table 6). The concentration of the main short-chain and saturated fatty acid percentage content in TFA-5.07\% (14:0), $11.47 \%(16: 0)$, and 2.24\% (18:0)—decreased in PUFAE distillated at $160{ }^{\circ} \mathrm{C}-0.66 \%(14: 0), 4.45 \%(16: 0)$, and $2.43 \%$ (18:0) (Table 6$)$.

To reduce thermal damage to the long chain PUFA, the highest temperatures used was $160{ }^{\circ} \mathrm{C}$. In fact, although the SPD technique is considered ideal for the separation of highly thermolabile components with minimal thermal degradation [71], operation conditions that include extremely high temperatures that could facilitate the separation of high molecular weight molecules are not recommended [72].

This temperature, in addition, granted the highest PUFA enrichment. PUFA increased in PUFAE (from $28.71 \%$ to $56.55 \%$ ), while in the EFA fraction, it was depleted $(30.19 \%$ ) (Table 6). Short-chain and saturated fatty acid percentage contents showed a significant decrease $(p<0.05)$ in PUFAE separated at $160^{\circ} \mathrm{C}$ by SPD respect to TFA (from $18.78 \%$ to $7.27 \%)$, though it remained almost constant in EFA (17.97\%). The total MUFA showed a significant decrease between TFA (52.51\%) and PUFAE (36.19\%), while no significant variation was observed in EFA (51.84\%) (Table 6).

The parameter R, defined as the concentration of EPA plus DHA to that of 16:0 plus 18:1 [72], confirmed the increase in PUFAE from 0.74 to 2.45 in TFA, while it was constant 
in EFA (0.68) $(p<0.05)$ (Table 6). Similarly, the ratio between PUFA and the short-chain and saturated fatty acid percentage contents also increased in PUFAE respect to TFA (from 1.54 to 7.79) (Table 6). As a consequence, respect to TFA, the content of EPA and DHA increased $(p<0.05)$ in PUFAE from 1.58 to 2.78 , respectively. The PUFA trend showed a general enrichment of 1.97 (Table 6). Breivik et al. [73], applying SPD at $125^{\circ} \mathrm{C}$ on fatty acid ethyl esters from sardine oil, obtained an enrichment of 1.77 folds in EPA and of 1.6 fold in DHA. More recently, Valverde et al. [74] obtained an enrichment of 1.8 folds in EPA at $200{ }^{\circ} \mathrm{C}$.

Our data, according to those reported for different oils [70,71,74-76], confirmed that SPD is an effective separation technology that can be used to concentrate PUFAs, in particular EPA and DHA, as ethyl esters from fish oil.

\subsection{In Vitro Bioactive Properties of the Refined Oil}

Many studies have underlined the beneficial effects of fish oils in cellular homeostasis, oxidative stress, and cardiovascular disease prevention and general health $[77,78]$, thus rendering the test of these properties for new produced oils very useful in view of its commercialization. An in vitro test is an ideal and consolidated experimental model system that is able to confirm in reliable and fast way some bioactive properties exerted by natural compounds, such as refined oils, in view of its further industrial applications $[35,38,79]$. In view of these considerations, toxicity, antioxidant properties, and modulation of adipogenesis were the main issues we considered in our work to address these oils in human consumption and fish meal inclusion.

The effects of CVO, RVO, PUFAE, and EFA on the viability of 3T3 L1 cells exposed to an oxidative stress induced by hydrogen peroxide $\left(\mathrm{H}_{2} \mathrm{O}_{2} ; \mathrm{HP}\right)$ treatment are reported in Figure 3.

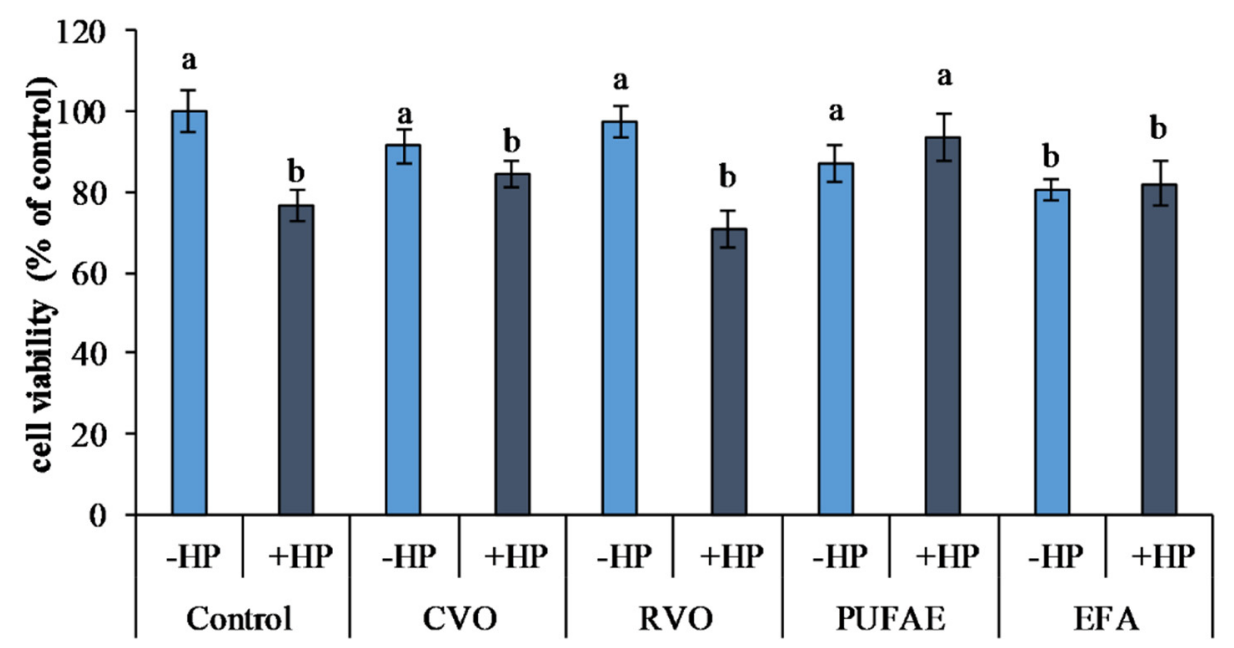

Figure 3. Effects of hydrogen peroxide $(\mathrm{HP})(50 \mu \mathrm{M})$ induced oxidative stress and treatment with crude viscera oil (CVO), refined viscera oil (RVO), PUFA-enriched fraction (PUFAE), and short chain and unsaturated fatty acid-enriched fraction exhausted in fatty acid ethyl esters ((EFA) on the viability of 3T3 L1 cells. Different letters indicate significant differences $(p<0.05)$.

Oxidative stress induced by hydrogen peroxide (control plus HP) determined a significant reduction of viability $(p<0.05)$ with respect to untreated cells (control minus HP) (Figure 3) in 3T3 L1 cells.

Compared to the controls not exposed to oxidative stress (control minus HP), treatments with CVO (CVO minus HP), RVO (RVO minus HP), and PUFAE (PUFAE minus HP) in cells not exposed to oxidative stress did not undergo a variation in cell viability. In 3T3 L1 cells exposed to EFA without oxidative stress induction (EFA minus HP), a significant reduction of viability $(p<0.05)$ was observed compared to both controls and CVO, RVO, and PUFAE treatments without oxidative stress induction (Figure 3). 
Oxidative stress induction by hydrogen peroxide determined a viability reduction in control cells (control plus HP) and cells treated with CVO, RVO, and EFA (CVO plus HP, RVO plus HP, and EFA plus HP), compared to the controls not exposed to oxidative stress (control minus HP) (Figure 3).

On the contrary, the preliminary treatment of 3T3 L1 cells with PUFAE exerted a marked protective effect. Furthermore, viability was higher in PUFAE and HP with respect to the control plus HP and all other treatments exposed to oxidative stress (CVO plus HP, RVO plus HP, and EFA plus HP) $(p<0.05)$ (Figure 3).

The reported results (Figure 3 ) suggested that treatment with PUFA exerted a protective effect against oxidative stress, as described by Sakai et al. [36] on human aortic endothelial cells, where a significant reduction of cellular mortality after oxidative stress induced by hydrogen peroxide after EPA and DHA treatment was reported [36].

Similarly, Kusunoki et al. [35] observed a protective effect of $\omega-3$ PUFA on 3T3-L1 against hydrogen peroxide-induced oxidative stress, confirming the well-known beneficial properties of these bioactive molecules for human health [35].

The bioactive properties of the PUFAE were also studied in fish cell line adipogenesis by evaluating morphology variation during the differentiation of $D$. labrax pre-adipocytes induced by PUFAE and EFA.

D. labrax pre-adipocytes started to differentiate after cell culture confluence (sixth day), in presence of factors-stimulating adipogenesis in the culture medium (L15); the differentiation was attested by the accumulation of lipid drops (Figure 4b); on the contrary, D. labrax pre-adipocytes, deprived of the adipogenic differentiation inducers in the culture medium, did not differentiate (Figure 4a).

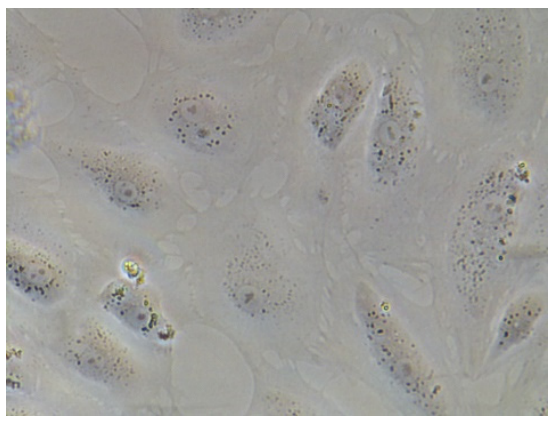

(a)

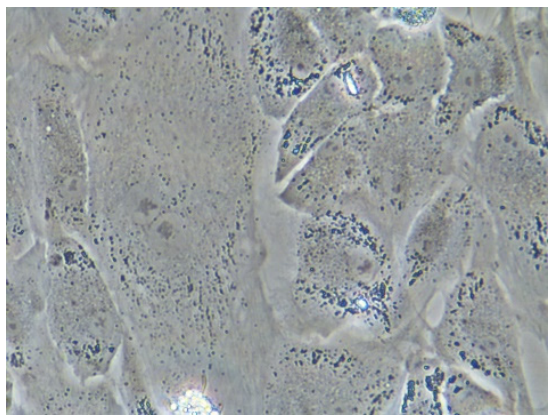

(c)

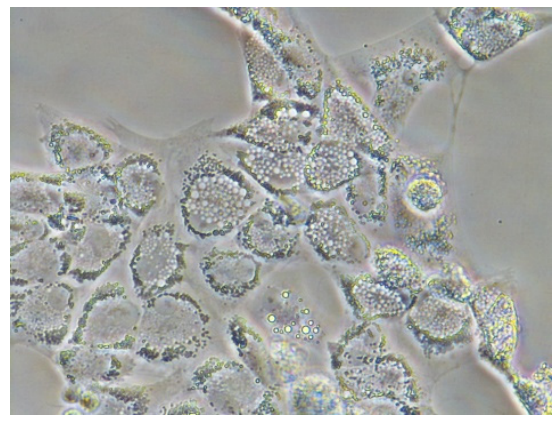

(b)

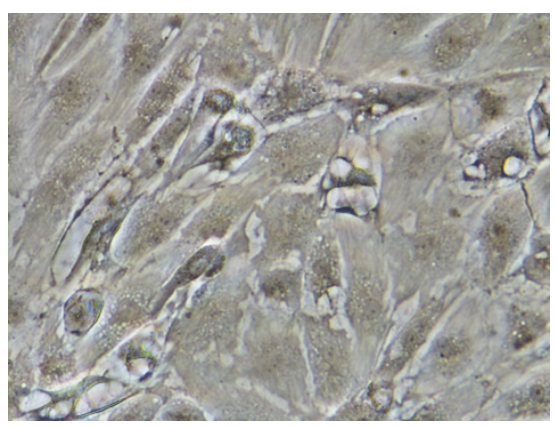

(d)

Figure 4. D. labrax pre adipocytes under differentiation (representative phase-contrast images at $40 \times$ magnification): (a) control undifferentiated cells; (b) differentiated adipocyte, induced by standard differentiation medium; (c) differentiated adipocyte-induced by medium supplemented with PUFAE; (d) differentiated adipocytes, induced by medium supplemented with EFA.

In D. labrax pre-adipocyte culture, the presence of PUFAE, after the initial steps of differentiation, stopped the increases volume and number of lipid droplet (Figure 4c), and the resulting undifferentiated adipocytes were almost similar to the undifferentiated controls (Figure $4 \mathrm{a}$ ) in both form and size, indicating the anti-adipogenic effect of this 
treatment. On the contrary, EFA treatment promoted a significant lipid accumulation (Figure 4d). The accumulation of cytoplasmatic lipid droplets was moderate during the first three days, but it increased significantly on the fourth day up to a total adipocyte hypertrophy on the seventh day (Figure $4 \mathrm{~d}$ ), thus suggesting that EFA may stimulated fat uptake and fat cytoplasm accumulation [38].

These findings were in agreement with results describing the anti-adipogenic effects of EPA and DHA during induced pre-adipocyte differentiation in cobia (Rachycentron canadum) [79], Atlantic salmon [80], and rainbow trout [38].

It is well-known that the fatty acid composition of the diet influences the fatty acid composition of fish $[33,41,43,47]$, and that this well-recognized property represents the basis of the artificial diet formulations in aquaculture that are aimed to increase growth performance while maintaining high quality. Growth performance and quality are mainly influenced by the energy content of the artificial diets, integrated by the addition of vegetal oils, rich in monounsaturated and omega- 6 fatty acids, by patterns of lipid distribution and metabolic management $[43,45,81]$. These formulations and the consequent high caloric contents are often responsible of the excessive fat deposition in farmed fish compared to the wild $[43,45]$, which is recognized as the principle issue related to oxidative stress and consequent peroxidation due to its negative effects on fish welfare, quality, and consumer perception. In this sense, research actions aimed to preliminarily evaluate the effects of oil composition on antioxidant prevention and lipid deposition are useful to assess the nutritional properties of new formulations.

Our in vitro observations confirmed that PUFAs have a significant effects on lipid metabolism and can influence the deposition of lipids in adipocytes, suggesting a possible effect on fat deposition in fish fillet. Therefore, regulating the composition of fatty acids in the diet could strategically change the lipid deposition in various tissues and, consequently, the lipid profile of the edible parts of fish.

However, further studies are needed to understand how, through dietary manipulation, it is possible to modulate the adiposity in fish fillets in order to obtain a higher quality product.

\section{Materials and Methods}

\subsection{Sampling}

SBV was sampled at the "Acqua Azzurra s.r.l". intensive aquaculture and fish processing farm (Pachino, SR, Italy), immediately placed on ice, transported to the laboratory, grinded, divided into aliquots of $500 \mathrm{~g}$, and stored in zip-lock polyethylene bags at $-80^{\circ} \mathrm{C}$, pending further analysis; treatments as summarized in Figure 5.

\subsection{Proximate Composition and Fatty Acid Profile}

The SBV proximate composition was evaluated by determining water and ash [82], crude protein [83], and total lipid [84] contents.

The fatty acid methyl ester profile of viscera lipids was determined, after transesterification, by GC using a Perkin Elmer Clarus ${ }^{\circledR} 580$ gas chromatograph (Perkin Elmer, Shelton, CT, USA) under previous conditions [21].

\subsection{Extraction of Crude Oil}

CVO was extracted from $20 \mathrm{~kg}$ SBV batches by wet extraction [49].

Preheated distilled water was added to ground SBV at a 1:2 $w / v$ ratio, and the mixture was incubated in a $50 \mathrm{~L}$ steel reactor equipped with an internal heating coil.

Extraction trials were performed under constant agitation at different temperatures $\left(40,60,80\right.$, and $\left.90^{\circ} \mathrm{C}\right)$ and for different reaction periods (10, 30, and $\left.60 \mathrm{~min}\right)$.

Extraction mixtures were filtered on a $125 \mu \mathrm{m}$ mesh sieve to remove the coarse particulates. The filtrate liquid phase was centrifuged at a centrifugal force of $40,000 \times g$ by a continuous tubular centrifuge (CEPA, Carl Padberg, Zentrifugenbau GmbH, Lahr/Schwarzwald, Germany) equipped with a separating cylinder (type TR). 


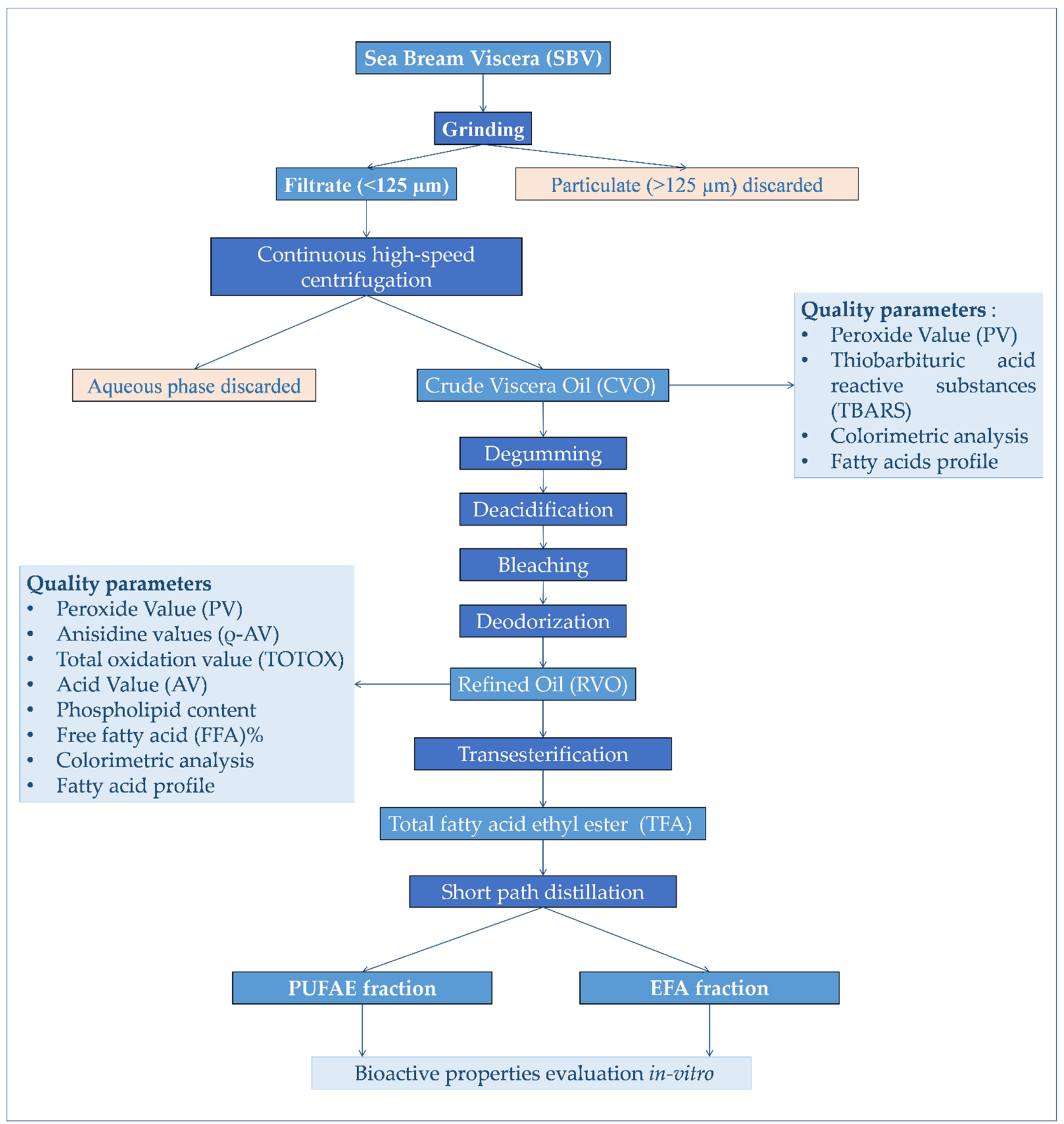

Figure 5. Experimental design adopted for the processing and production of $\omega$-3-enriched-oil, as well as the evaluation of its bioactivity in vitro.

The extraction mixture was fed at the bottom of the cylinder by a Masterflex L/S peristaltic pump equipped with tubing L/S 18 (Cole-Parmer s.r.l., Mi, Italy), with a throughputs of $0.03 \mathrm{~L} \mathrm{~min}^{-1}$. This configuration allowed us to separate contemporary and continuously solids (retained in the cylinder), a heavy liquid phase (containing protein and cellular end tissue debris), and a light liquid phase (containing CVO) that exited the cylinder in two separate fluxes. $\mathrm{CVO}$ samples were stored at $-20^{\circ} \mathrm{C}$ in $2.5 \mathrm{~L}$ dark bottles under nitrogen. 


\subsection{Chemical Refining Process of $\mathrm{CVO}$}

The CVO refining process (Figure 5) was carried out in $5 \mathrm{~L}$ batches. During the refining process, when required, all liquid phase separation was carried out by a continuous tubular centrifuge equipped with a separating cylinder, as described above.

CVO was degummed and neutralized following the procedure of Chakraborty and Joseph [61].

After degumming and neutralization, CVO bleaching was done to remove color compounds by treatment through a column of activated charcoal powder $(5 \% w / w$ of $\mathrm{CVO})$.

Bleached CVO was deodorized at low temperatures by a VLK 70-4 short path distillation unit (VTA Gmbh; Niederwinkling, Germany). Bleached CVO was kept at $60^{\circ} \mathrm{C}$ during the process and continuously fed into the feed vessel by a peristaltic pump (feeding rate $3 \mathrm{~L} / \mathrm{h}$ ) at an evaporator temperature of $120^{\circ} \mathrm{C}$, a condenser temperature of $25^{\circ} \mathrm{C}$, a vacuum of 5 mbar, and a rotor speed of $400 \mathrm{rpm}$.

At the end of the refining process, RVO was collected as the residual phase of SPD and stored at $-20{ }^{\circ} \mathrm{C}$ in $2.5 \mathrm{~L}$ dark bottles under nitrogen, pending further analyses and processing.

\subsection{Assessment of Oil Quality}

The refining process was evaluated using commercial cod liver oil as the CO (Pearson, Campo Ligure, Ge, Italy). The quality of $\mathrm{CVO}$ and $\mathrm{RVO}$ was evaluated during the various refining steps by monitoring PV, TBARS, $\rho-\mathrm{AV}$, TOTOX, phospholipid content, and free fatty acid (FFA) $\%$, as well as through colorimetric analysis.

\subsubsection{Peroxide Value (PV)}

Aliquots $(1.0 \mathrm{~g})$ of oil samples were used for PV determination. PV, expressed in milliequivalents of active oxygen per $\mathrm{kg}$ of oil $\left(\mathrm{meqO}_{2} / \mathrm{kg}\right)$, was evaluated by iodometric titration with a standard solution of sodium thiosulphate [85].

\subsubsection{Thiobarbituric Acid Reactive Substances Analysis (TBARS)}

TBARS analysis was carried out on $0.1 \mathrm{~g}$ aliquots of oil following the work of Botsoglou et al. [86]. Spectrophotometric quantification was performed at $532 \mathrm{~nm}$ with a UV-Vis spectrophotometer (Cary 50, Varian Inc., Palo Alto, CA, USA) using a standard

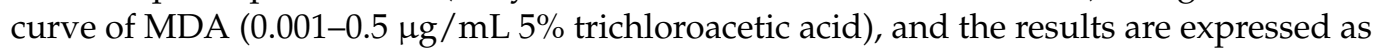
content of MDA $\mu \mathrm{g} / \mathrm{g}$.

\subsubsection{Content of $\rho$-Anisidine ( $\rho-\mathrm{AV})$}

The $\rho$-AV was assessed according to the official AOCS method [87] slightly modified by Honold et al. [48]. Spectrophotometric quantification was performed by assessing the absorbance of each sample $(0.5 \mathrm{~g})$ at $350 \mathrm{~nm}$ (As) using a UV-Vis spectrophotometer (Cary 50, Varian Inc., Palo Alto, CA, USA) against a blank (Ab) (5 mL Chloroform with $1 \mathrm{~mL}$ $\rho$-anisidine solution) (Sigma, Aldrich).

The $\rho-\mathrm{AV}$ calculation is given by Equation (1):

$$
\rho-A V=(25 x(1.2 A s-A b)) /(\text { sample weight }(g))
$$

\subsubsection{Total Oxidation Value (TOTOX)}

TOTOX was determined according to Holm [88] and calculated using Equation (2):

$$
\text { TOTOX }=(2 \times P V)+\rho-A V
$$

\subsubsection{Phospholipid Content}

The phospholipids, in crude and refined oil, were separated from the total triglycerides by siliceous matrix columns (HF Bond Elut SI, $100 \mathrm{mg}, 1 \mathrm{~mL}$, Varian, Palo Alto, CA, USA) by adding $0.1 \mathrm{~g}$ of $\mathrm{CVO}$ and $\mathrm{RVO}$ diluted in $1 \mathrm{~mL}$-hexane to the top of column and 
flushing the column with $20 \mathrm{~mL}$ of chloroform to separate triglycerides in the eluate. The column was then flushed with $20 \mathrm{~mL}$ of methanol and the eluate to recover phospholipids, the contents of which were then determined gravimetrically.

\subsubsection{Acid Value}

Acid value was evaluated on aliquots of $1 \mathrm{~g}$ of oil sample according to the official AOCS method [89] by acid-base titration using an ethanol solution of potassium hydroxide ( $\mathrm{KOH} 0.1 \mathrm{~N}$ in ethanol 96\%) as the titrant and phenolphthalein as the indicator.

The acid value was expressed as \% oleic acid equivalent according to Formula (3) [90]:

$$
\% \text { FFA }(\text { oleic acid })=((V c-V b) \times N \times 28.8) /(\text { sample weight }(g))
$$

where $\mathrm{Vc}$ is volume of the titrant solution used for the sample, $\mathrm{Vb}$ is the volume of the titrant solution for the blank, and $\mathrm{N}$ is $\mathrm{KOH}$ concentration.

\subsubsection{Colorimetric Analysis}

The color analysis was performed following the work of Sathivel et al. [49] on three replicates of each sample $(1 \mathrm{~mL})$ by a Konika Minolta CR 400 spectrophotometer (Konica Minolta Chroma Co., Osaka, Japan). Results are expressed by the parameters of $\mathrm{L}^{*}$, $\mathrm{a}^{*}$, and $b^{*}$ and by derived variables of color saturation $\left(C^{*}\right)$, hue angle $(h)$, and total color variation $(\Delta \mathrm{E})[55]$.

\subsection{PUFA Enrichment}

Batches of 2.5 L of RVO were trans esterified to obtain ethyl esters TFAs without the use of any solvent other than ethanol [91].

During transesterification, all liquid phase separations were carried out by a continuous tubular centrifuge equipped with a separating cylinder, as described above.

Batches of 2 L of TFA were distilled by SPD using the VLK 70-4 molecular distillation unit (VTA Gmbh, Niederwinkling, Germany) with an evaporating surface of $4.8 \mathrm{dm}^{2}$.

Before PUFA enrichment, to remove impurities and any solvent traces, TFA underwent a degassing step.

TFA samples, preheated to $40{ }^{\circ} \mathrm{C}$, were loaded into the feed vessel (at $40{ }^{\circ} \mathrm{C}$ ) by a peristaltic pump. Distillation trials were run utilizing the following operating conditions: feeding vessel at $40{ }^{\circ} \mathrm{C}$, condenser at $25^{\circ} \mathrm{C}$; evaporator at 140,150 , or $160{ }^{\circ} \mathrm{C}\left(120{ }^{\circ} \mathrm{C}\right.$ for degassing); feeding rate of $300 \mathrm{~mL} / \mathrm{h}(500 \mathrm{~mL} / \mathrm{h}$ for degassing); roller speed of $400 \mathrm{rpm}$; and vacuum of $<0.01$ mbar ( 5 mbar for degassing).

PUFAE (heavy phase) and EFA (distilled phase) were collected, and yields were determined gravimetrically.

In order to evaluate the enrichment process every 1.0 L TFA feed and at the end of distillation, aliquots of the two separated phases were diluted at $1 \%$ in c-hexane to analyze fatty acid profiles by GC.

On the basis of the fatty acid profile, the following indices were calculated:

- $\quad$ EPA and DHA\%.

- $\quad$ Fatty acid ratio ${ }^{\circledR}(4)[72]$ :

$$
R=([E P A]+[D H A]) /([16: 0]+[18: 1 \omega 9])
$$

- $\quad$ Enrichment factor for EPA, DHA, and PUFA.

- $\quad$ Ratio of total PUFA to total saturated fatty acids (PUFA/saturated).

\subsection{In Vitro Bioactive Properties}

3T3 L1 mouse cell lines (ECACC n. 86052701, Sigma ${ }^{\circledR}$ (Sigma-Aldrich, Saint Louis, MO, USA) were cultured in $75 \mathrm{~cm}^{2}$ plastic flasks (Nunc, Darmstadt, Germany) in Dulbecco's Modified Eagle's Medium (DMEM) supplemented with 10\% calf serum, 2 mM glutamine, 
and $100 \mu \mathrm{g} / \mathrm{mL}$ of penicillin-streptomycin (all reagents from Sigma-Aldrich, Saint Louis, $\mathrm{MO}, \mathrm{USA})$; they were incubated in a humidified atmosphere $\left(\mathrm{CO}_{2} 5 \%\right)$.

Cells were seeded in 96-well plates at a concentration of $7 \times 10^{3}$ cells/well and incubated for $24 \mathrm{~h}$. After $24 \mathrm{~h}$, the cells were treated (three replicates) with CVO, RVO, PUFAE, and EFA dissolved in ethanol at a concentration of $5 \mu \mathrm{g} / \mathrm{mL}$ in the medium, with a final solvent concentration of $0.1 \%(v / v)$, and left to incubate for $24 \mathrm{~h}$.

As attested by internal routine procedures [92], ethanol did not exert any detrimental effects when used as vehicle.

After a preliminary test, aimed to assess the dose/dependent toxicity of the oils in a concentration range of $1-5 \mu \mathrm{g} / \mathrm{mL}$, a final concentration of $5 \mu \mathrm{g} / \mathrm{mL}$ was selected for the bioactivity test.

After $24 \mathrm{~h}$ of incubation, control cells and cells incubated with CVO, RVO, PUFAE, and EFA were exposed to oxidative stress by $50 \mu \mathrm{M}$ hydrogen peroxide, according to a previous standardized protocol [92-95], and incubated at $37^{\circ} \mathrm{C}$ for $2 \mathrm{~h}$.

The viability was determined by the [3-(4,5-dimethylthiazol-2-yl)-2,5-diphenyltetrazolium bromide] (MTT) method according to Mosman [96]. The optical densities (ODs) at $570 \mathrm{~nm}$ with background subtraction at 690 were determined in a microplate reader (Multiscan-Sky Microplate Reader, Thermo-Scientific TM, USA).

The percentage of viability was determined by Formula (5):

$$
\text { Viability }(\%)=\left(\frac{\text { OD of the test sample }}{\text { OD of the control sample }}\right) \times 100
$$

OD measurements were performed in triplicate.

D. labrax pre-adipocytes were maintained in an L-15 Leibowitz medium (Sigma, London, UK) supplemented with $10 \%$ fetal bovine serum (FBS, Sigma, UK), 2 mM L-glutamine (Sigma, UK), 10 mM 4-(2-hydroxyethyl)-1-piperazine ethane sulfonic acid (HEPES; Sigma, $\mathrm{UK}$ ), and penicillin-streptomycin solution (Sigma, UK), and they were seeded in $25 \mathrm{~cm}^{2}$ plastic tissue culture flasks (Nunc, Germany). The cells were kept at $20^{\circ} \mathrm{C}$, and the growth medium was changed every $2-3$ days. The cell culture reached confluence after approximately 1 week.

The differentiation of $D$. labrax pre-adipocytes was induced by the slightly modified differentiation-inducing medium described by Todorčević et al. [37].

The L-15 medium was supplemented with $1 \mu \mathrm{M}$ dexamethasone, $1 \mu \mathrm{M}$ isobutylmethylxanthine, $20 \mu \mathrm{g} / \mathrm{mL}$ of insulin, and $0.2 \mu \mathrm{L} / \mathrm{mL}$ of lipid mixture, corresponding to $45 \mathrm{mg} / \mathrm{mL}$ of cholesterol and $100 \mathrm{mg} / \mathrm{mL}$ of cod liver oil ethyl esters instead of methyl esters [37].

To study its effect on pre-adipocyte differentiation, the confluent pre-adipocyte culture was incubated as follows: (1) L15 medium deprived of adipocyte differentiation inducers (control), (2) pre-adipocyte standard differentiation medium, (3) pre-adipocyte standard differentiation medium supplemented with $0.2 \mu \mathrm{L} / \mathrm{mL}$ of PUFAE instead of $0.2 \mu \mathrm{L} / \mathrm{mL}$ of lipid mixture, (4) pre-adipocyte standard differentiation medium supplemented with $0.2 \mu \mathrm{L} / \mathrm{mL}$ of EFA instead of $0.2 \mu \mathrm{L} / \mathrm{mL}$ of lipid mixture.

The medium was changed every three days until the cells reached the final step of differentiation (the morphology of mature adipocytes) (21 days) [37,97].

Image Acquisition

Cells in the culture were observed daily using a Nikon Eclipse Ti-S inverted microscope (Nikon Instrument Inc., Melville, NY, USA), and images were captured by a Nikon DS-L3 digital camera (Nikon Corporation, Tokyo, Japan) and the DS-L3 Digital Camera Controller acquisition software. Images represent pre-adipocytes cells observed with phase contrast microscopy at $40 \times$ magnification. 


\subsection{Statistical Analysis}

Results are reported as mean \pm standard deviation. Observed differences among the effects of temperature and extraction time during the extractions were analyzed by an ANOVA [98]. Differences observed among results of the refining process were analyzed by Student $t$ tests. Cochran's $C$ test was used to test the assumption of variance homogeneity. Student-Newman-Keuls (SNK) post hoc tests were conducted for all significant interaction terms [98]. The differences were considered significant for $p<0.05$. All elaborations were performed using STATISTICA 7.0 (Statsoft Inc., Tulsa, OK, USA).

\section{Conclusions}

There is a wide and extensive body of literature attesting to the presence and properties of the bioactive compounds contained in marine discard, wastes, and processed by-products and that stimulate their utilization in diverse industrial sectors; moreover, there is a discrepancy between laboratory and industrial applications, as most results are valid only at the lab scale. This situation is responsible for the delay in innovation in the sector of marine biotechnology and blue-economy, which needs the implementation of procedures and protocols with high technological readiness levels (TRLs) in order to boost productivity and competitiveness. The present paper attests to the validity of the pilot protocol for processing high volumes of industrial aquaculture by-products in high volumes of enriched fish oil in view of its application in the real world. This example could stimulate the adoption of solutions aimed to recover and utilize aquaculture by-products at a higher scale, turning "waste into profit" and indicating a strategy to reach more sustainable business models in aquaculture resource utilization according to the principles of the circular economy.

We started from an extensive study on the chemical and nutritional characterization of sea bream by-products (crude and enriched oil extracted from SBV), followed by bioactivity evaluation.

The obtained results showed that SBV is a very suitable source among sea bream waste because it is very rich in lipids and therefore an excellent matrix for the production of fish oils. Crude oils showed good characteristics, and refined oils were found to be adequate for a direct human consumption according to the current European Food Safety Authority (EFSA) guidelines. In addition, SPD was found to be a simple, economical, and environmentally sustainable technique that resulted in a product containing up to $56 \%$ long-chain PUFAs. Furthermore, the in vitro approach represents a fast and reliable way to appreciate the effects of oil in cells in view of its application for nutraceutical uses and feed formulations in aquaculture to ensure an optimal degree of reared fish adiposity.

Our study confirms the potential recycling of fish by-products for conversion into products of higher value and the reduction of the impact of the aquaculture sector, improving its economic performance and conforming to zero waste strategies.

Supplementary Materials: The following are available online at https:/ / www.mdpi.com/1660-339 7/19/3/160/s1, Table S1: CIELAB colour coordinates $\left(\mathrm{L}^{*}, \mathrm{a}^{*}, \mathrm{~b}^{*}\right.$, Chromaticity- $\mathrm{C}^{*}$, tint angle-h and total color variation $-\triangle \mathrm{E})$ in crude viscera oil (CVO) extracted from sea bream viscera (SBV) at different temperatures $\left({ }^{\circ} \mathrm{C}\right)$ and reaction time $(\mathrm{min})$. Commercial Cod liver oil $(\mathrm{CO})$ was used as control. Table S2: CIELAB colour coordinates $\left(\mathrm{L}^{*}, \mathrm{a}^{*}, \mathrm{~b}^{*}\right.$, Chromaticity $-\mathrm{C}^{*}$, tint angle- $\mathrm{h}$ and total color variation $-\triangle \mathrm{E})$ in crude viscera oil $(\mathrm{CVO})$ and refined viscera oil $(\mathrm{RVO})$. Commercial Cod liver oil (CO) was used as control. Figure S1: Crude viscera oils (CVO) extracted from sea bream viscera (SBV) at different temperatures. $\left(40^{\circ} \mathrm{C}, 60^{\circ} \mathrm{C}\right.$ and $\left.80^{\circ} \mathrm{C}\right)$.

Author Contributions: Conceptualization, A.S. and C.M.M.; methodology, A.S. and C.M.M.; validation, A.S. and C.M.M.; formal analysis, R.A., L.L.B., G.R., S.M., G.F. (Giovanna Ficano), V.A.L. and G.F. (Gioacchino Fazio); investigation, R.A., S.M. and C.M.M.; resources, A.S.; data curation, A.S. and C.M.M.; writing—original draft preparation, R.A., L.L.B., G.R. and S.M.; writing-review and editing, C.M.M. and A.S.; supervision, C.M.M. and A.S.; funding acquisition, A.S. All authors have read and agreed to the published version of the manuscript. Authorship must be limited to those who have contributed substantially to the work reported. 
Funding: This research was partially supported by the project Innovazione tecnologica a supporto dell'incremento della produttività e della competitività dell'acquacoltura siciliana-PON02_00667.

Conflicts of Interest: The authors declare no conflict of interest.

\section{References}

1. Coppola, D.; Lauritano, C.; Esposito, F.P.; Riccio, G.; Rizzo, C.; de Pascale, D. Fish Waste: From Problem to Valuable Resource. Mar. Drugs 2021, 19, 116. [CrossRef] [PubMed]

2. García-De-Vinuesa, A.; Demestre, M.; Carreño, A.; Lloret, J. The Bioactive Potential of Trawl Discard: Case Study from A Crinoid Bed off Blanes (North-Western Mediterranean). Mar. Drugs 2021, 19, 83. [CrossRef]

3. Alfio, V.G.; Manzo, C.; Micillo, R. From Fish Waste to Value: An Overview of the Sustainable Recovery of Omega-3 for Food Supplements. Molecules 2021, 26, 1002. [CrossRef]

4. Lund, E.K. Health benefits of seafood; Is it just the fatty acids? In Proceedings of the Food Chemistry; Elsevier: Amsterdam, The Netherlands, 2013; Volume 140, pp. 413-420.

5. Rimm, E.B.; Appel, L.J.; Chiuve, S.E.; Djoussé, L.; Engler, M.B.; Kris-Etherton, P.M.; Mozaffarian, D.; Siscovick, D.S.; Lichtenstein, A.H. A Seafood Long-Chain n-3 Polyunsaturated Fatty Acids and Cardiovascular Disease: A Science Advisory From the American Heart Association. Circulation 2018, 138, e35-e47. [CrossRef] [PubMed]

6. Zárate, R.; El Jaber-Vazdekis, N.; Tejera, N.; Pérez, J.A.; Rodríguez, C. Significance of long chain polyunsaturated fatty acids in human health. Clin. Transl. Med. 2017, 6, 1-19. [CrossRef]

7. Caruso, G.; Floris, R.; Serangeli, C.; Di Paola, L. Fishery Wastes as a Yet Undiscovered Treasure from the Sea: Biomolecules Sources, Extraction Methods and Valorization. Mar. Drugs 2020, 18, 622. [CrossRef]

8. Pateiro, M.; Munekata, P.E.S.; Domínguez, R.; Wang, M.; Barba, F.J.; Bermúdez, R.; Lorenzo, J.M. Nutritional Profiling and the Value of Processing By-Products from Gilthead Sea Bream (Sparus aurata). Mar. Drugs 2020, 18, 101. [CrossRef]

9. Marsol-Vall, A.; Aitta, E.; Guo, Z.; Yang, B. Green technologies for production of oils rich in n-3 polyunsaturated fatty acids from aquatic sources. Crit. Rev. Food Sci. Nutr. 2021, 1-21. [CrossRef]

10. Mentoor, I.; Engelbrecht, A.-M.; Nell, T. Fatty acids: Adiposity and breast cancer chemotherapy, a bad synergy? Prostaglandins Leukot. Essent. Fat. Acids 2019, 140, 18-33. [CrossRef] [PubMed]

11. Tarasiuk, A.; Mosińska, P.; Fichna, J. The mechanisms linking obesity to colon cancer: An overview. Obes. Res. Clin. Pr. 2018, 12, 251-259. [CrossRef] [PubMed]

12. Field, C.J.; Schley, P.D.; Brindley, D.N. Omega-3 polyunsaturated fatty acids alter raft lipid composition and decrease epidermal growth factor receptor levels in lipid rafts of human breast cancer cells. FASEB J. 2007, 21, A165. [CrossRef]

13. Siddiqui, R.A.; Harvey, K.; Stillwell, W. Anticancer properties of oxidation products of docosahexaenoic acid. Chem. Phys. Lipids 2008, 153, 47-56. [CrossRef]

14. Omabe, M.; Ezeani, M.; Omabe, K.N. Lipid metabolism and cancer progression: The missing target in metastatic cancer treatment. J. Appl. Biomed. 2015, 13, 47-59. [CrossRef]

15. Mozaffarian, D.; Wu, J.H.Y. Omega-3 fatty acids and cardiovascular disease: Effects on risk factors, molecular pathways, and clinical events. J. Am. Coll. Cardiol. 2011, 58, 2047-2067. [CrossRef]

16. Zamora-Sillero, J.; Gharsallaoui, A.; Prentice, C.; Vázquez, J.A.; Meduíña, A.; Durán, A.I.; Nogueira, M.; Fernández-Compás, A.; Pérez-Martín, R.I.; Rodríguez-Amado, I.; et al. Impact of omega-3 polyunsaturated fatty acids on vascular function and blood pressure: Relevance for cardiovascular outcomes. Circulation 2019, 138, 191-200.

17. Guillen, J.; Natale, F.; Carvalho, N.; Casey, J.; Hofherr, J.; Druon, J.-N.; Fiore, G.; Gibin, M.; Zanzi, A.; Martinsohn, J.T. Global seafood consumption footprint. Ambio 2019, 48, 111-122. [CrossRef]

18. Turchini, G.M.; Ng, W.K.; Tocher, D.R. Fish Oil Replacement and Alternative Lipid Sources in Aquaculture Feeds; CRC Press: Boca Raton, FL, USA, 2010; ISBN 9781439808634.

19. Shepherd, C.J.; Jackson, A.J. Global fishmeal and fish-oil supply: Inputs, outputs and marketsa. J. Fish Biol. 2013, 83, 1046-1066. [CrossRef]

20. Fountoulaki, E.; Vasilaki, A.; Hurtado, R.; Grigorakis, K.; Karacostas, I.; Nengas, I.; Rigos, G.; Kotzamanis, Y.; Venou, B.; Alexis, M. Fish oil substitution by vegetable oils in commercial diets for gilthead sea bream (Sparus aurata L.); effects on growth performance, flesh quality and fillet fatty acid profile. Aquaculture 2009, 289, 317-326. [CrossRef]

21. Messina, C.M.; Renda, G.; La Barbera, L.; Santulli, A. By-products of farmed European sea bass (Dicentrarchus labrax L.) as a potential source of n-3 PUFA. Biologia 2013, 68, 288-293. [CrossRef]

22. Messina, M.; Piccolo, G.; Tulli, F.; Cardinaletti, G.; Tibaldi, E. Lipid composition and metabolism of European sea bass (Dicentrarchus labrax L.) fed diets containing wheat gluten and legume meals as substitutes for fish meal. Aquaculture 2013, 376-379, 6-14. [CrossRef]

23. Monge-Ortiz, R.; Tomás-Vidal, A.; Rodriguez-Barreto, D.; Martínez-Llorens, S.; Pérez, J.; Jover-Cerdá, M.; Lorenzo, A. Replacement of fish oil with vegetable oil blends in feeds for greater amberjack (Seriola dumerili) juveniles: Effect on growth performance, feed efficiency, tissue fatty acid composition and flesh nutritional value. Aquac. Nutr. 2018, 24, 605-615. [CrossRef]

24. Torrecillas, S.; Mompel, D.; Caballero, M.; Montero, D.; Merrifield, D.; Rodiles, A.; Robaina, L.; Zamorano, M.; Karalazos, V.; Kaushik, S.; et al. Effect of fishmeal and fish oil replacement by vegetable meals and oils on gut health of European sea bass (Dicentrarchus labrax). Aquaculture 2017, 468, 386-398. [CrossRef] 
25. Šimat, V.; Vlahović, J.; Soldo, B.; Skroza, D.; Ljubenkov, I.; Mekinić, I.G. Production and Refinement of Omega-3 Rich Oils from Processing By-Products of Farmed Fish Species. Foods 2019, 8, 125. [CrossRef] [PubMed]

26. Rustad, T.; Storrø, I.; Slizyte, R. Possibilities for the utilisation of marine by-products. Int. J. Food Sci. Technol. 2011, 46, 2001-2014. [CrossRef]

27. Antelo, L.T.; Lopes, C.; Franco-Uría, A.; Alonso, A.A. Fish discards management: Pollution levels and best available removal techniques. Mar. Pollut. Bull. 2012, 64, 1277-1290. [CrossRef] [PubMed]

28. Galanakis, C.M. Recovery of high added-value components from food wastes: Conventional, emerging technologies and commercialized applications. Trends Food Sci. Technol. 2012, 26, 68-87. [CrossRef]

29. Stevens, J.R.; Newton, R.W.; Tlusty, M.; Little, D.C. The rise of aquaculture by-products: Increasing food production, value, and sustainability through strategic utilisation. Mar. Policy 2018, 90, 115-124. [CrossRef]

30. Maschmeyer, T.; Luque, R.; Selva, M. Upgrading of marine (fish and crustaceans) biowaste for high added-value molecules and bio(nano)-materials. Chem. Soc. Rev. 2020, 49, 4527-4563. [CrossRef]

31. Villamil, O.; Váquiro, H.; Solanilla, J.F. Fish viscera protein hydrolysates: Production, potential applications and functional and bioactive properties. Food Chem. 2017, 224, 160-171. [CrossRef]

32. Ucak, I.; Afreen, M.; Montesano, D.; Carrillo, C.; Tomasevic, I.; Simal-Gandara, J.; Barba, F. Functional and Bioactive Properties of Peptides Derived from Marine Side Streams. Mar. Drugs 2021, 19, 71. [CrossRef]

33. Cervera, M.; Ángel, R.; Venegas, E.V.; Bueno, R.P.R.; Medina, M.D.S.; Guerrero, J.L.G. Docosahexaenoic acid purification from fish processing industry by-products. Eur. J. Lipid Sci. Technol. 2015, 117, 724-729. [CrossRef]

34. Šimat, V.; Vlahović, J.; Soldo, B.; Mekinić, I.G.; Čagalj, M.; Hamed, I.; Skroza, D. Production and characterization of crude oils from seafood processing by-products. Food Biosci. 2020, 33, 100484. [CrossRef]

35. Kusunoki, C.; Yang, L.; Yoshizaki, T.; Nakagawa, F.; Ishikado, A.; Kondo, M.; Morino, K.; Sekine, O.; Ugi, S.; Nishio, Y.; et al. Omega-3 polyunsaturated fatty acid has an anti-oxidant effect via the Nrf-2/HO-1 pathway in 3T3-L1 adipocytes. Biochem. Biophys. Res. Commun. 2013, 430, 225-230. [CrossRef] [PubMed]

36. Sakai, C.; Ishida, M.; Ohba, H.; Yamashita, H.; Uchida, H.; Yoshizumi, M.; Ishida, T. Fish oil omega-3 polyunsaturated fatty acids attenuate oxidative stress-induced DNA damage in vascular endothelial cells. PLoS ONE 2017, 12, e0187934. [CrossRef] [PubMed]

37. Todorčević, M.; Vegusdal, A.; Gjøen, T.; Sundvold, H.; Torstensen, B.E.; Kjær, M.A.; Ruyter, B. Changes in fatty acids metabolism during differentiation of Atlantic salmon preadipocytes; Effects of n-3 and n-9 fatty acids. Biochim. Biophys. Acta (BBA)-Mol. Cell Biol. Lipids 2008, 1781, 326-335. [CrossRef]

38. Riera-Heredia, N.; Lutfi, E.; Sánchez-Moya, A.; Gutiérrez, J.; Capilla, E.; Navarro, I. Short-Term Responses to Fatty Acids on Lipid Metabolism and Adipogenesis in Rainbow Trout (Oncorhynchus mykiss). Int. J. Mol. Sci. 2020, 21, 1623. [CrossRef] [PubMed]

39. Hathwar, S.C.; Bijinu, B.; Rai, A.K.; Narayan, B. Simultaneous Recovery of Lipids and Proteins by Enzymatic Hydrolysis of Fish Industry Waste Using Different Commercial Proteases. Appl. Biochem. Biotechnol. 2011, 164, 115-124. [CrossRef] [PubMed]

40. Vázquez, J.A.; Meduíña, A.; Durán, A.I.; Nogueira, M.; Fernández-Compás, A.; Pérez-Martín, R.I.; Rodríguez-Amado, I. Production of Valuable Compounds and Bioactive Metabolites from By-Products of Fish Discards Using Chemical Processing, Enzymatic Hydrolysis, and Bacterial Fermentation. Mar. Drugs 2019, 17, 139. [CrossRef]

41. Sinanoglou, V.; Houhoula, D.; Kyrana, V.; Lougovois, V. Visceral oil from farmed Sparus aurata, Dicentrarchus labrax and Diplodus puntazzo as a source of $\omega$-3 PUFA. Czech J. Food Sci. 2017, 35, 414-423. [CrossRef]

42. Kandyliari, A.; Mallouchos, A.; Papandroulakis, N.; Golla, J.P.; Lam, T.T.; Sakellari, A.; Karavoltsos, S.; Vasiliou, V.; Kapsokefalou, M. Nutrient Composition and Fatty Acid and Protein Profiles of Selected Fish By-Products. Foods 2020, 9, 190. [CrossRef]

43. Lenas, D.S.; Triantafillou, D.J.; Chatziantoniou, S.; Nathanailides, C. Fatty acid profile of wild and farmed gilthead sea bream (Sparus aurata). J. Consum. Prot. Food Saf. 2011, 6, 435-440. [CrossRef]

44. Gelibolu, S.; Yanar, Y.; Genc, M.A.; Genç, E. Effect of Mannan-oligosaccharide Supplementation on Body Growth, Fatty Acid Profile and Organ Morphology of Gilthead Seabream, Sparus aurata. Pak. J. Zool. 2018, 50, 229-240. [CrossRef]

45. Grigorakis, K. Compositional and organoleptic quality of farmed and wild gilthead sea bream (Sparus aurata) and sea bass (Dicentrarchus labrax) and factors affecting it: A review. Aquaculture 2007, 272, 55-75. [CrossRef]

46. Y1ldız, M.; Eroldoğan, T.O.; Ofori-Mensah, S.; Engin, K.; Baltac1, M.A. The effects of fish oil replacement by vegetable oils on growth performance and fatty acid profile of rainbow trout: Re-feeding with fish oil finishing diet improved the fatty acid composition. Aquaculture 2018, 488, 123-133. [CrossRef]

47. Benedito-Palos, L.; Bermejo-Nogales, A.; Karampatos, A.I.; Ballester-Lozano, G.F.; Navarro, J.C.; Diez, A.; Bautista, J.M.; Bell, J.G.; Tocher, D.R.; Obach, A.; et al. Modelling the predictable effects of dietary lipid sources on the fillet fatty acid composition of one-year-old gilthead sea bream (Sparus aurata L.). Food Chem. 2011, 124, 538-544. [CrossRef]

48. Honold, P.J.; Nouard, M.-L.; Jacobsen, C. Fish oil extracted from fish-fillet by-products is weakly linked to the extraction temperatures but strongly linked to the omega-3 content of the raw material. Eur. J. Lipid Sci. Technol. 2015, 118, 874-884. [CrossRef]

49. Sathivel, S.; Prinyawiwatkul, W.; King, J.M.; Grimm, C.C.; Lloyd, S. Oil production from catfish viscera. J. Am. Oil Chem. Soc. 2003, 80, 377-382. [CrossRef]

50. Chantachum, S. Separation and quality of fish oil from precooked and non-precooked tuna heads. Food Chem. 2000, 69, 289-294. [CrossRef] 
51. Genç, ÍY.; Esteves, E.; Aníbal, J.; Diler, A. Effects of different thawing methods on the quality of meagre fillets. Ankara Üniv. Vet. Fak. Derg. 2015, 62, 153-159. [CrossRef]

52. Food and Agriculture Organization of the United Nations. Codex Alimentarius Commision Standard for Fish Oil. In Codex Stan; Food and Agriculture Organization of the United Nations: Rome, Italy, 2017; p. 329.

53. Yin, H.; Solval, K.M.; Huang, J.; Bechtel, P.J.; Sathivel, S. Effects of Oil Extraction Methods on Physical and Chemical Properties of Red Salmon Oils (Oncorhynchus nerka). J. Am. Oil Chem. Soc. 2011, 88, 1641-1648. [CrossRef]

54. Eke-Ejiofor, J.A. Effect of Extraction Methods on the Quality Characteristics of Catfish (Clarias gariepinus) Oil. Am. J. Food Sci. Technol. 2018, 6, 199-203. [CrossRef]

55. CIE. Commission Internationale de l'Eclairage Colorimetry, 3rd ed.; CIE 0152004 Color; CIE: Tiruchirappalli, India, 2004; Volume 15, pp. $1-82$.

56. Shabanpour, B.; Asghari, M.; Heydari, S.; Baee, H.; Ghorbani, A.; Jafar, A. Comparing of qualitative changes among the carps culturing in a pond, an under controlled place and marine carp during refrigeration. J. Anim. Res. Iran. J. Biol. 2016, 28, 466-480.

57. Sabzipour, F.; Naseri, M.; Babaei, S.; Imani, A. Effect of various postmortem processing times and blanching methods on quality of rainbow trout (Oncorhynchus mykiss) waste oil. Food Sci. Nutr. 2019, 7, 3093-3102. [CrossRef]

58. Franklin, E.C.; Haq, M.; Roy, V.C.; Park, J.; Chun, B. Supercritical $\mathrm{CO}_{2}$ extraction and quality comparison of lipids from Yellowtail fish (Seriola quinqueradiata) waste in different conditions. J. Food Process. Preserv. 2020, 44, 1-12. [CrossRef]

59. Yves, H.; Korma, S.A.; Ali, A.H.; Tuyishime, M.A.; Habinshuti, I.; Abed, S.M. Extraction, Refining and Purification of $\omega-3$ PUFA through Different Techniques-A Review. Am. J. Food Sci. Nutr. Res. 2016, 4, 18-26. [CrossRef]

60. European Food Safety Authority. Scientific Opinion on Fish Oil for Human Consumption. Food Hygiene, including Rancidity. EFSA J. 2010, 8, 1-48. [CrossRef]

61. Chakraborty, K.; Joseph, D. Production and Characterization of Refined Oils Obtained from Indian Oil Sardine (Sardinella longiceps). J. Agric. Food Chem. 2015, 63, 998-1009. [CrossRef]

62. Kuo, C.-H.; Liao, H.-Z.; Wang, Y.-H.; Wang, H.-M.D.; Shieh, C.-J.; Tseng, C.-Y. Highly efficient extraction of EPA/DHA-enriched oil from cobia liver using homogenization plus sonication. Eur. J. Lipid Sci. Technol. 2017, 119, 1-8. [CrossRef]

63. FAO. A Joint FAO/WHO Food Standards Programme Codex Committee on Fats and Oils. Codex Alimentarius Commission, Procedural Manual, 20th ed.; FAO: Rome, Italy, 2011.

64. Soldo, B.; Šimat, V.; Vlahović, J.; Skroza, D.; Ljubenkov, I.; Mekinić, I.G. High Quality Oil Extracted from Sardine By-Products as an Alternative to Whole Sardines: Production and Refining. Eur. J. Lipid Sci. Technol. 2019, 121, 1-10. [CrossRef]

65. Mei, L.; Wang, L.; Li, Q.; Yu, J.; Xu, X. Comparison of acid degumming and enzymatic degumming process forSilybum marianumseed oil. J. Sci. Food Agric. 2013, 93, 2822-2828. [CrossRef]

66. Vaisali, C.; Charanyaa, S.; Belur, P.D.; Regupathi, I. Refining of edible oils: A critical appraisal of current and potential technologies. Int. J. Food Sci. Technol. 2014, 50, 13-23. [CrossRef]

67. Chaiyasit, W.; Elias, R.J.; McClements, D.J.; Decker, E.A. Role of Physical Structures in Bulk Oils on Lipid Oxidation. Crit. Rev. Food Sci. Nutr. 2007, 47, 299-317. [CrossRef] [PubMed]

68. García-Moreno, P.J.; Guadix, A.; Gómez-Robledo, L.; Melgosa, M.; Guadix, E.M. Optimization of bleaching conditions for sardine oil. J. Food Eng. 2013, 116, 606-612. [CrossRef]

69. Afaq, F.; Malik, A.; Syed, D.; Maes, D.; Matsui, M.S.; Mukhtar, H. Pomegranate Fruit Extract Modulates UV-B-mediated Phosphorylation of Mitogen-activated Protein Kinases and Activation of Nuclear Factor Kappa B in Normal Human Epidermal Keratinocytes. Photochem. Photobiol. 2005, 81, 38-45. [CrossRef] [PubMed]

70. Oliveira, A.C.M.; Miller, M.R. Purification of Alaskan Walleye Pollock (Gadus chalcogrammus) and New Zealand Hoki (Macruronus novaezelandiae) Liver Oil Using Short Path Distillation. Nutrients 2014, 6, 2059-2076. [CrossRef] [PubMed]

71. Solaesa, Á.G.; Sanz, M.T.; Falkeborg, M.; Beltrán, S.; Guo, Z. Production and concentration of monoacylglycerols rich in omega-3 polyunsaturated fatty acids by enzymatic glycerolysis and molecular distillation. Food Chem. 2016, 190, 960-967. [CrossRef]

72. Liang, J.-H.; Hwang, L.S. Fractionation of squid visceral oil ethyl esters by short-path distillation. J. Am. Oil Chem. Soc. 2000, 77, 773-777. [CrossRef]

73. Breivik, H.; Haraldsson, G.G.; Kristinsson, B. Preparation of highly purified concentrates of eicosapentaenoic acid and docosahexaenoic acid. J. Am. Oil Chem. Soc. 1997, 74, 1425-1429. [CrossRef]

74. Valverde, L.M.; Moreno, P.A.G.; Callejón, M.J.J.; Cerdán, L.E.; Medina, A.R. Concentration of eicosapentaenoic acid (EPA) by selective alcoholysis catalyzed by lipases. Eur. J. Lipid Sci. Technol. 2013, 115, 990-1004. [CrossRef]

75. Wang, W.; Li, T.; Ning, Z.; Wang, Y.; Yang, B.; Ma, Y.; Yang, X. A process for the synthesis of PUFA-enriched triglycerides from high-acid crude fish oil. J. Food Eng. 2012, 109, 366-371. [CrossRef]

76. Zhang, Y.; Wang, X.; Xie, D.; Zou, S.; Jin, Q.; Wang, X. Synthesis and concentration of 2-monoacylglycerols rich in polyunsaturated fatty acids. Food Chem. 2018, 250, 60-66. [CrossRef]

77. Fard, S.G.; Wang, F.; Sinclair, A.J.; Elliott, G.; Turchini, G.M. How does high DHA fish oil affect health? A systematic review of evidence. Crit. Rev. Food Sci. Nutr. 2019, 59, 1684-1727. [CrossRef]

78. Dong, S.; Huang, X.; Zhen, J.; Van Halm-Lutterodt, N.; Wang, J.; Zhou, C.; Yuan, L. Dietary Vitamin E Status Dictates Oxidative Stress Outcomes by Modulating Effects of Fish Oil Supplementation in Alzheimer Disease Model APPswe/PS1dE9 Mice. Mol. Neurobiol. 2018, 55, 9204-9219. [CrossRef] [PubMed] 
79. Cheng, Y.-C.; Chen, H.-Y. Effects of different fatty acids on cell differentiation and lipid accumulation in preadipocytes of warm water fish cobia (Rachycentron canadum Linnaeus, 1766). Aquac. Res. 2013, 46, 590-601. [CrossRef]

80. Vegusdal, A.; Sundvold, H.; Gjøen, T.; Ruyter, B. An in vitro method for studying the proliferation and differentiation of Atlantic salmon preadipocytes. Lipids 2003, 38, 289-296. [CrossRef] [PubMed]

81. Santulli, A.; Messina, C.M.; D'Amelio, V. Variations of lipid and apolipoprotein content in lipoproteins during fasting in European sea bass (Dicentrarchus labrax L.). Comp. Biochem. Physiol. Part A Physiol. 1997, 118, 1233-1239. [CrossRef]

82. AOAC International. Official Methods of Analysis of AOAC International, 18th ed.; Horwitz, W., Ed.; AOAC International: Gaithersburg, MD, USA, 2005; ISBN 978-0-935584-75-2.

83. AOAC. AOAC Association of Official Analytical Chemists Official Method, 981.10 Crude protein in meat block digestion method. J. AOAC Int. 1992, 65, 1339 .

84. Folch, J.; Lees, M.; Stanley, G.S. A simple method for the isolation and purification of total lipids from animal tissues. J. Biol. Chem. 1957, 226, 497-509. [CrossRef]

85. AOCS. AOCS Peroxide value. In Official Methods and Recommended Practices of the American Oil Chemists' Society Official Method Cd 8-53; AOCS Press: Champaign, IL, USA, 1998.

86. Botsoglou, N.A.; Fletouris, D.J.; Papageorgiou, G.E.; Vassilopoulos, V.N.; Mantis, A.J.; Trakatellis, A.G. Rapid, Sensitive, and Specific Thiobarbituric Acid Method for Measuring Lipid Peroxidation in Animal Tissue, Food, and Feedstuff Samples. J. Agric. Food Chem. 1994, 42, 1931-1937. [CrossRef]

87. AOCS. AOCS Sampling and Analysis of Commercial Fats and Oil: $\rho$-Anisidine Value, Official Method Cd 18-90; AOAC International: Gaithersburg, MD, USA, 1993.

88. Holm, U. Abstracts, International Society for Fat Research Congress; ISF: Urbana, IL, USA, 1972.

89. AOCS. AOCS Method Cd 3d-63. Acid Value. In Official Methods and Recommended Practices of the AOCS, 5th ed.; AOCS Press: Champaign, IL, USA, 1999.

90. Aryee, A.N.A.; Simpson, B.K.; Phillip, L.E.; Cue, R.I. Effect of Temperature and Time on the Stability of Salmon Skin Oil During Storage. J. Am. Oil Chem. Soc. 2011, 89, 287-292. [CrossRef]

91. Vazquez, L.; Akoh, C.C. Fractionation of Short and Medium Chain Fatty Acid Ethyl Esters from a Blend of Oils via Ethanolysis and Short-Path Distillation. J. Am. Oil Chem. Soc. 2010, 87, 917-928. [CrossRef]

92. Messina, C.M.; Manuguerra, S.; Renda, G.; Santulli, A. Biotechnological Applications for the Sustainable Use of Marine Byproducts: In Vitro Antioxidant and Pro-apoptotic Effects of Astaxanthin Extracted with Supercritical $\mathrm{CO}_{2}$ from Parapeneus longirostris. Mar. Biotechnol. 2019, 21, 565-576. [CrossRef] [PubMed]

93. Abbes, M.; Baati, H.; Guermazi, S.; Messina, C.; Santulli, A.; Gharsallah, N.; Ammar, E. Biological properties of carotenoids extracted from Halobacterium halobium isolated from a Tunisian solar saltern. BMC Complement. Altern. Med. 2013, 13, 1-8. [CrossRef] [PubMed]

94. Manuguerra, S.; Caccamo, L.; Mancuso, M.; Arena, R.; Rappazzo, A.C.; Genovese, L.; Santulli, A.; Messina, C.M.; Maricchiolo, G. The antioxidant power of horseradish, Armoracia rusticana, underlies antimicrobial and antiradical effects, exerted in vitro. Nat. Prod. Res. 2018, 34, 1567-1570. [CrossRef] [PubMed]

95. Messina, C.M.; Troia, A.; Arena, R.; Manuguerra, S.; Ioannou, T.; Curcuraci, E.; Renda, G.; Hellio, C.; Santulli, A. Species-Specific Antioxidant Power and Bioactive Properties of the Extracts Obtained from Wild Mediterranean Calendula Spp. (Asteraceae). Appl. Sci. 2019, 9, 4627. [CrossRef]

96. Mosmann, T. Rapid colorimetric assay for cellular growth and survival: Application to proliferation and cytotoxicity assays. J. Immunol. Methods 1983, 65, 55-63. [CrossRef]

97. Ljubojević, D.B.; Pelic, M.; Novakov, N.; Lazić, S.; Lupulović, D.; Ćirković, M.; Todorčević, M. The establishment of the cell culture of preadipocytes of common carp (Cyprinus carpio L.). Food Feed. Res. 2014, 41, 103-108. [CrossRef]

98. Underwood, A.J. Experiments in Ecology. Their Logical Design and Interpretation Using Analysis of Variance; Cambridge University Press: Cambridge, UK, 1997; ISBN 0521556961. 